Discussion Paper No. 14-050

What Old Stagers Could Teach Us -

Examining Age Complementarities in Regional Innovation Systems

Melanie Arntz and Terry Gregory

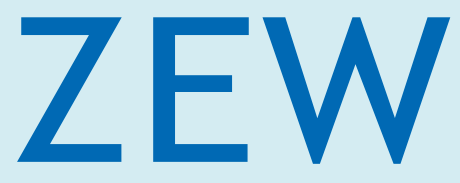

Zentrum für Europäische Wirtschaftsforschung $\mathrm{GmbH}$

Centre for European

Economic Research 
Discussion Paper No. 14-050

\section{What Old Stagers Could Teach Us - Examining Age Complementarities in Regional Innovation Systems}

Melanie Arntz and Terry Gregory

Download this ZEW Discussion Paper from our ftp server:

http://ftp.zew.de/pub/zew-docs/dp/dp14050.pdf

Die Discussion Papers dienen einer möglichst schnellen Verbreitung von neueren Forschungsarbeiten des ZEW. Die Beiträge liegen in alleiniger Verantwortung der Autoren und stellen nicht notwendigerweise die Meinung des ZEW dar.

Discussion Papers are intended to make results of ZEW research promptly available to other economists in order to encourage discussion and suggestions for revisions. The authors are solely responsible for the contents which do not necessarily represent the opinion of the ZEW. 


\title{
What Old Stagers Could Teach Us - Examining Age Complementarities in Regional Innovation Systems*
}

\author{
Melanie Arntz ${ }^{\dagger}$ \\ ZEW Mannheim 83 University of Heidelberg \\ Terry Gregory $\ddagger$ \\ ZEW Mannheim
}

July 2014

\begin{abstract}
Concerns have been raised that demographic ageing may weaken the competitiveness of knowledge-based economies and increase regional disparities. The age-creativity link is however far from clear at the aggregate level. Contributing to this debate, we estimate the causal effect of the workforce age structure on patenting activities for local labour markets in Germany using a flexible knowledge production function and accounting for potential endogeneity of the regional workforce structure. Overall, our results suggest that younger workers boost regional innovations, but this effect partly hinges on the presence of older workers as younger and older workers turn out to be complements in the production of knowledge. With demographic aging mainly increasing the older workforce and shrinking the younger one, our results imply that innovation levels in ageing societies may drop in the future. Moreover, differences in the regional age structure currently explain around a sixth of the innovation gap across German regions.
\end{abstract}

Keywords: regional innovation system, demographic ageing, knowledge production function, regional disparities, age complementarities

JEL: R12, R23, J11

${ }^{*}$ The authors thank the scholars at: 19th annual meetings of the Society of Labor Economists (SOLE), Annual Meeting of the European Economic Association (EEA), 8th European workshop on "Labour Markets and Demographic Change", 53rd annual congress of the European Regional Science Association (ERSA), Annual Meeting of the the German Regional Science Association (GfR), 6th Geoffrey J.D. Hewings Regional Economics Workshop, seminars at the Universities of Regensburg, Mannheim, Heidelberg, Kassel and at the Lower Saxony Institute for Economic Research (NIW) we well as Duncan Roth and Stephan Dlugosz for helpful comments. All remaining errors are the authors sole responsibility. We further thank the Fritz Thyssen Foundation for financial support and the German Stifterverband for regional data on research and development expenditures.

${ }^{\dagger}$ Melanie Arntz is Assistant Professor at the University of Heidelberg and Senior Research Fellow at the Centre for European Economic Research (ZEW) Mannheim, L7, 1 D-68161 Mannheim, e-mail: arntz@zew.de, phone: +49621 1235159, fax: +49621 1235225.

${ }^{\ddagger}$ Terry Gregory (corresponding author) is Research Fellow at the Centre for European Economic Research (ZEW) Mannheim, L7, 1 D-68161 Mannheim, e-mail: gregory@zew.de, phone: +49621 1235306, fax: +49 621 1235225 . 


\section{Introduction}

With accelerating demographic ageing in most industrialized economies, concerns have been raised that an ageing workforce may reduce creative performance and thus, ultimately, the competitiveness of the affected countries in the global, knowledge-based economy. These concerns are fueled by numerous studies on the creative performance of scientists and artists that suggest a peak productivity in middle-ages and a declining performance thereafter (Lehman, 1953. Simonton, 1988, Oster and Hamermesh, 1998; Bratsberg et al., 2003, Jones, 2010) 11 However, age-related declines in mental abilities must not necessarily translate into a diminishing innovative performance at the aggregate level if there are knowledge externalities between ageheterogenous individuals with complementary skills. The reason is that whereas younger workers are endowed with higher abilities in generating and recombining new knowledge, older workers tend to be have accumulated more experience and knowledge in how to use and apply existing skills (Horn and Cattell, 1967). Knowledge spillovers may then arise from formal and informal interactions within and between firms and might compensate for possible disadvantages of individual ageing. This is particularly true for knowledge-based economies with a higher demand for interactive skills (Autor et al. 2003) that are relatively stable over the life cycle (Skirbekk, 2004). Existing studies on the more aggregated level are far from conclusive though.

At the firm level, studies based on cross-sectional data tend to find a hump-shaped ageproductivity profile (Hellerstein et al., 1996; Haltiwanger et al., 1999; Lallemand and Rycx, 2009), whereas studies dealing with the endogeneity of the firm's workforce age by applying panel estimations and instrumental variable techniques suggest either no or even positive effects of older workers on firm productivity (Cardoso et al., 2011, Dostie, 2011; Van Ours and Stoeldraijer, 2011, Göbel and Zwick, 2012). The later findings may hint at the suggested age complementarities within firms and which might be partly compensating for declining mental abilities. In fact, a firm-level study by Backes-Gellner and Veen (2013) argues in this direction and shows that companies involved in creative tasks benefit from an age-diverse workforce.

At the macro level, studies on the link between workforce age structure and regional performance measures are much scarcer although knowledge spillovers between firms have been found to be important drivers of innovation (Feldman and Florida, 1994; Audretsch and Feldman, 1996). Using more general indicators of economic performance, few country-level studies

\footnotetext{
${ }^{1}$ This hump-shaped pattern also seems to hold for general work productivity, see (Skirbekk, 2004) for a review.
} 
investigate the link between the workforce age and GDP growth Lindh and Malmberg, 1999; Prskawetz et al., 2007) or total factor productivity (Feyrer, 2008). Overall, these studies find a hump-shaped pattern even when applying panel and instrumental variable estimators. At the regional level, a hump-shaped pattern has been found by Brunow and Hirte (2006) for GDP growth, by Bönte et al. (2009) for the firm formation rate, and by Frosch and Tivig (2009) for the regional invention rate. Only Bönte et al. (2009) thereby plausibly solve the endogeneity of the regional workforce age by applying instrumental variables. Moreover, none of these studies investigates potential complementarities between different age groups.

This paper fills this research gap by examining the causal link between workforce age structure and patenting activity on the level of local labour markets and by investigating potential complementarities and substitutabilities between different age groups using flexible knowledge production functions. By doing so, the paper makes at least three contributions. First of all, we investigate the link between creative performance and age at the preferred unit of analysis. Previous studies have shown that the link between innovative inputs and outputs appears to be modelled best at a regional level, see Audretsch and Feldman (2004) for a detailed discussion. The relevance of the regional context for the generation of ideas appears to be driven by the spatially limited range of between-firm knowledge externalities which turns the regional level to the preferred unit of measuring the generation of innovations (Peri, 2005). Secondly, analyzing the age-creativity link for German labour market regions is of particular interest since Germany has the second highest median age behind Japan ${ }^{2}$ and, more importantly, is characterized by a striking demographic polarization across regions (Gregory and Patuelli, 2013). Thirdly, we address the endogeneity of the regional workforce age by using long lags of the regional population age structure, the share of bohemians and the public sector share for an Instrumental Variables (IV) approach. In addition, we compare both cross-sectional and panel estimations and control for potentially confounding factors such as public and private R\&D expenditures, the number of creative professionals, population density and the regional industry mix. We then run various specifications to shed light on the nature of the knowledge production function. For ease of comparison with many existing studies, we first estimate the age-creativity link by using age polynomials in order to derive the age-innovation profile. We then estimate a Translog production function using the number of young, middle-aged and older workers to gain insights into the complementarities and substitutabilities between these input factors.

\footnotetext{
${ }^{2}$ See http://esa.un.org/unpd/wpp/Documentation/pdf/WPP2012_HIGHLIGHTS.pdf .
} 
Overall, our results suggest a more complex pattern compared to the typically found humpshaped age-innovation profile from existing studies. In particular, our findings indicate that younger workers boost regional innovations, but that this effect partly hinges on the presence of older workers. Moreover, cross-partial derivatives from Translog production functions suggest that abilities of younger workers and the experience of older workers are complements in the production of knowledge. Despite this positive indirect effect of older workers on the production of knowledge, however, our findings point towards a reduced innovation level if demographic aging shrinks the size of the younger workforce considerably. Moreover, the difference in the age structure of the least and most innovative German regions explains around a sixth of the gap in innovative performance.

The paper is structured as follows. Section 2 discusses the spatial knowledge production function and gives a short literature review on relevant empirical evidence. Section 3 introduces the data which is briefly described in Section 4 . In Section 5 we describe the econometric approach before presenting the results in Section 6. Section 7 concludes.

\section{Regional knowledge production function}

The starting point for our analysis is the knowledge production function which originally has been thought of as operating on the firm level (Griliches, 1979). The knowledge production function describes the relationship between innovative inputs and outputs with $R \& D$ investments typically viewed as a main input factor. Whereas empirical studies at the country and industrylevel confirm the link between R\&D and innovations though (Scherer, 1983, Griliches, 1987; Acs and Audretsch, 1990), the link seems to be much weaker at the firm-level, thus indicating the presence of knowledge spillovers that go beyond the firm (Audretsch and Feldman, 2004). At the same time, such spillovers have been argued to be locally bounded since the transfer of knowledge seems to be linked to face-to-face interactions (Von Hippel, 1994 Manski, 2000). In fact, Peri (2005) shows that only $20 \%$ of technological knowledge is learned outside the region. Hence, the natural unit of measuring the generation of innovations appears to be the region, thus giving rise to the regional knowledge production function.

Regional knowledge production functions have been estimated with different measures of innovative outputs and inputs as well as at different spatial units. Jaffe (1989), for example, establishes a positive link between regional research activities by both private corporations 
and universities and regional patent activity. Using new product innovations as a measure of innovative output, spillovers from academic research and the relevance of corporate spending on R\&D have also been confirmed by Acs et al. (1992). Similar findings have been found for Austrian regions by Fischer and Varga (2003). In addition to R\&D, human capital has been added as a major input to the regional knowledge production function. In particular, skilled labour has been considered to serve as a main vehicle for knowledge spillovers (Malecki, 1997; Feldman, 1999). Consistent with this notion, Audretsch and Feldman (1996) find that industries with higher shares of skilled labour have a greater tendency to cluster spatially. Knowledge externalities thus seem to be closely linked to the skilled workforce, a notion that is also confirmed by empirical studies on patent activities in the US (Ceh, 2001).

Our approach considers the age of the human capital base to be a major additional input factor of the regional knowledge production function. In particular, we assume that the innovation output in region $i$ is a function of the age of the human capital base and other region-specific factors $S_{i}$ that have been found to affect the productivity of the regional innovation system. In particular, we consider $S_{i}$ to capture regional R\&D investments by private and public institutions, the skill mix of the regional workforce, a region's industry mix and the scale and density of the local labour market. All of these factors have been shown to affect the regional production of knowledge. For ease of comparison to studies estimating age-invention or age-productivity profiles, we first estimate a simple knowledge production function quadratic in the mean workforce age in region $i$ in addition to these controls and examine the age-innovation profile at the regional level, i.e. we estimate

$$
P_{i}=\alpha_{0}+\alpha_{1} M A G E_{i}+\alpha_{2} M A G E_{i}^{2}+\beta S_{i}+u_{i}
$$

where $M A G E_{i}$ corresponds to the mean age of the regional workforce, $\beta$ is a vector of coefficients for all regressors contained in $S_{i}$ and $u$ is the usual error component. However, this approach is highly restrictive and does not allow for further insights regarding the relevance of age complementarities.

Hence, we refine the knowledge production function to distinguish between the number of younger workers between 18 and $29\left(A_{1 i}\right)$, middle-aged workers between 30 and $49\left(A_{2 i}\right)$ and older workers above $50\left(A_{3 i}\right)$. The first group comprises young workers that have just completed their education, but who are relatively unexperienced in the labour market. The second group 
determines workers with increased experience and high productivity levels. Finally, the last group comprises the age group 50 plus for whom studies have shown that cognitive capacities are starting to decline, but who draw from a large stock of experience and skills on team work behaviour and problem solving in difficult situations. For instance, Börsch-Supan and Weiss (2011) conduct an analysis for an assembly plant of a truck manufacturer and find that older workers, though making more errors, are more able to grasp difficult situations and concentrate on the vital tasks. The results are in line with past evidence that suggests fluid abilities (speed of problem-solving and abstract reasoning) to decrease at older ages, whereas crystallized abilities (ability to use skills, knowledge and experience) remain at high functional levels until a late age in life (Horn and Cattell, 1967). We argue that the skills and experience of older workers may be complementary to young and relatively unexperienced workers, especially in a knowledge based economy. In fact, other studies have also argued in favour of such age-related skills and complementarities (Schneider, 2008, Göbel and Zwick, 2012, Backes-Gellner and Veen, 2013).

In order to allow for complex patterns of complementarity and substitutability between the age groups, we start with the most flexible functional form, the CES-Translog production function, and test whether the more restrictive Translog, CES and Cobb-Douglas production technologies are suitable approximations of the CES-Translog. As will be discussed in Section 6.2 the Translog production function turns out to be a suitable fit for the production of knowledge. The main estimations later on are thus based on estimating the Translog production function with

$$
P=A_{1}^{\alpha_{1}} A_{2}^{\alpha_{2}} A_{3}^{\alpha_{3}} e^{\left(S+\beta_{1} \ln A_{1}^{2}+\beta_{2} \ln A_{2}^{2}+\beta_{3} \ln A_{3}^{2}+\gamma_{12} \ln A_{1} \ln A_{2}+\gamma_{13} \ln A_{1} \ln A_{3}+\gamma_{23} \ln A_{2} \ln A_{3}+u\right)}
$$

where the index $i$ has been dropped for simplicity. The Translog production function allows for non-linear relations and interactions between any pair of inputs, i.e. it allows for a broad range of potentially non-constant substitution possibilities.

Note that the additional determinants of innovative performance $S$ in Equation (2) are considered to be exogeneous drivers of innovative performance that are not interacted with the three differently aged labour inputs. Although this is restrictive, especially regarding the potential complementarities between education and experience, we decided to impose this restriction in order to keep a manageable amount of parameters and to ease the estimation of the above equation by means of an IV strategy, see Section 5 for details. 
We estimate the Translog production function by a log-log specification of Equation (2) and calculate the marginal products as well as the degree of complementarity or substitutability between the different labour inputs using the estimated parameters. In particular, we calculate the marginal products of each age group as

$$
\begin{aligned}
\frac{\partial P}{\partial A_{1}} & =\frac{P}{A_{1}}\left(\alpha_{1}+2 \beta_{1} \ln A_{1}+\gamma_{12} \ln A_{2}+\gamma_{13} \ln A_{3}\right):=\frac{P}{A_{1}} Z_{1} \\
\frac{\partial P}{\partial A_{2}} & =\frac{P}{A_{2}}\left(\alpha_{2}+2 \beta_{2} \ln A_{2}+\gamma_{12} \ln A_{1}+\gamma_{23} \ln A_{3}\right):=\frac{P}{A_{2}} Z_{2} \\
\frac{\partial P}{\partial A_{3}} & =\frac{P}{A_{3}}\left(\alpha_{3}+2 \beta_{3} \ln A_{3}+\gamma_{13} \ln A_{1}+\gamma_{23} \ln A_{2}\right):=\frac{P}{A_{3}} Z_{3}
\end{aligned}
$$

where $Z_{1}, Z_{2}$ and $Z_{3}$ represent the elasticities of patent performance with respect to young, middle-aged, and older workers. Note that $Z_{j}$ with $j=1,2,3$ determines whether a particular age group increases or decreases the regional productivity in terms of knowledge generation.

We then compute the second order derivative for each input factors that corresponds to the change in the previous marginal product with the size of the particular input factor:

$$
\begin{gathered}
\sigma_{11}=\frac{\partial^{2} P}{\partial A_{1}^{2}}=\frac{P}{A_{1}^{2}}\left(Z_{1}^{2}+2 \beta_{1}-Z_{1}\right) \\
\sigma_{22}=\frac{\partial^{2} P}{\partial A_{2}^{2}}=\frac{P}{A_{2}^{2}}\left(Z_{2}^{2}+2 \beta_{2}-Z_{2}\right) \\
\sigma_{33}=\frac{\partial^{2} P}{\partial A_{3}^{2}}=\frac{P}{A_{3}^{2}}\left(Z_{3}^{2}+2 \beta_{3}-Z_{3}\right) .
\end{gathered}
$$

Finally, we compute the degree of complementarity or substitutability between the three input factors by estimating the following cross-partial derivatives

$$
\begin{gathered}
\sigma_{12}=\frac{\partial^{2} P}{\partial A_{1} \partial A_{2}}=\frac{P}{A_{1} A_{2}}\left(Z_{1} Z_{2}+\gamma_{12}\right) \\
\sigma_{13}=\frac{\partial^{2} P}{\partial A_{1} \partial A_{3}}=\frac{P}{A_{1} A_{3}}\left(Z_{1} Z_{3}+\gamma_{13}\right) \\
\sigma_{23}=\frac{\partial^{2} P}{\partial A_{2} \partial A_{3}}=\frac{P}{A_{2} A_{3}}\left(Z_{2} Z_{3}+\gamma_{23}\right) .
\end{gathered}
$$

with $\gamma_{j k}(j \neq k)$ as the estimated coefficient of the interaction of the two groups of workers in Equation (2). The cross-partial derivative gives the change of the marginal product of age group $j$ for a change in the quantity of age group $k$. The cross-partial derivative thus yields insights into how the expansion of one age group affects the patent performance of another age group. In particular, any pair of inputs $A_{j}$ and $A_{k}$ are complements (substitutes) if $\sigma_{j k}>0$ 
$\left(\sigma_{j k}<0\right) !^{3}$ We calculate these cross-partial derivatives at the mean of the sample based on the log-log specification of our knowledge production function and use the delta method to derive at standard errors.

\section{Data}

The following data is calculated at the level of local labour markets as defined by Kosfeld and Werner (2012). This classification comprises 141 local labour markets in Germany that have been functionally delineated based on commuting time ${ }^{4}$ and do not necessarily follow political boundaries. For each of these 141 regions, we calculate the number of regional innovations as well as demographic and regional indicators on a yearly basis for the time period 1994-2008.

As a measure for innovative outcome in the regional knowledge production function we use regional patent activity. There are several advantages and disadvantages of using patenting data at the regional level 5 On the one hand, patent applications are a useful indicator of research and invention activities at the local level, as they include information on the regional origin of inventor activities, i.e. place of residence and therefore indirectly the location of the process of knowledge generation. On the other hand, not every invention becomes the subject of a patent application, nor does a patent necessarily become a marketable product or process. Moreover, the reasons for a patent application may not only rest on protecting an invention against unjustified use, but may reflect strategic concerns such as securing and extending regional markets, prestige advertisement and the demonstration of innovative capacity to the economic competitors. Despite these disadvantages, empirical evidence by Acs et al. (2002), who provide an exploratory and a regression-based comparison of the innovation counts and patent counts at the lowest possible level of geographical aggregation, suggests that patents provide a fairly reliable measure of innovative activity. Also, the survey provided by Griliches (1998) concludes that patents are a good indicator of differences in inventive activity across different firms.

For this reason, we use patent data that is provided by the European Patent Office (EPO)

\footnotetext{
${ }^{3}$ Alternatively, one might calculate the Hicks partial elasticity of complementarity (HEC) (Sato and Koizumi 1973). The HEC measures the effect on the relative factor price of two input factors that is induced by changes in the relative quantities of these inputs. However, this is a meaningful interpretation only if we assume that the above production function is actually at the core of the profit maximization by firms operating on a competitive market with given output prices. Since patents are not the output sold at the market, we find it implausible to choose such a measure, but stick to the cross-partial derivatives of the production function in order to assess the complementarity of the labour inputs.

${ }_{4}^{4}$ Kosfeld and Werner (2012) use a factor analysis based on the commuting time that is reasonable given the size and attractiveness of the region's center (maximally 45 to 60 minutes), see Figure 1

${ }^{5}$ For a detailed discussion see Giese and von Reinhard Stoutz (1998) and Giese $(2002)$.
} 
in order to measure regional innovations between 1994 and 2008 on a yearly basis. The data contains patent applications both at the applicant and inventor level. Whereas the applicant is the holder of the patent right, the inventors are the actual inventors cited in the document. We focus on patent inventors since we are interested in the spatial distribution of the actual inventors rather than the location of the formal holder of the patent, which is often one of the firm's headquarters. Since patents may have been developed by several inventors located in different regions, we apply a fractional counting approach to assign to every region the respective share of the patent. For instance, an inventor who developed a patent in region $i$ with one further individual working abroad would generate 0.5 patents for region $i$. As a robustness check, we will also use the number of citations of all regional patents as an alternative, more quality-weighted measures of regional innovations.

For the calculation of the age structure of the regional workforce, we make use of the regional file of the Sample of Integrated Labour Market Biographies (SIAB) from the Institute of Employment Research (IAB). This administrative data set is provided by the German Federal Employment Agency and contains a two percent subsample of all workers that are subject to social insurance contributions by their employers, thus excluding civil servants and self-employed individuals. The data includes individual employment histories on a daily basis and contains, among others, information on the age, education and occupation of workers as well as the labour market region of each workplace. We are thus able to compute age and skill characteristics of the regional workforce rather than the regional population. We consider this to be an advantage because regional innovations should be linked to the regional workforce rather than to those living, but not necessarily working in the labour market area, although the distinction should be of no major concern if most commuting takes place within labour market regions. Furthermore, we restrict the analysis to the employed adult workforce. Although knowledge spillovers are not completely restricted to the employed workforce, it is nonetheless unlikely that unemployed workers will participate in the relevant knowledge interactions. The same holds for underage workers who are typically undergoing a vocational training.

For computing the regional workforce characteristics on a yearly basis, we use annual cross sections at the cut-off date June 30th. In particular, we calculate the regional workforce size, the mean age of the regional workforce as well the number and share of workers between 18-29, 30-49 and those above 50 years of age. In addition, we extract further control variables such as the share of workers in certain industries (16 categories) and the share of low-, medium-, 
and high-skilled workers. Furthermore, following the arguments laid out by Florida (2002), we calculate the number of creative professionals and bohemians ${ }^{6}$ of a region since the generation of ideas and innovation seems to largely depend on creative professionals working in the field of education, engineering and science. Bohemians such as artists and publishers, on the other hand, have been argued to create a local milieu that subsequently attracts creative professionals, a link that we will exploit in our IV approach.

As additional control variables, we use information on population density and public research and development (R\&D) expenditures (regular and external funding) as provided by the German Statistical Office (Destatis). Moreover, we use rich data collected by the German Stifterverband, that includes private R\&D expenditures at a regional level.

\section{Descriptives}

In order to get first insights into the age-innovation link at the regional level, Figure 1 maps the mean age of the regional workforce and the regional patent count averaged across the period 1994 to 2008. The regions are classified into quintiles of the respective distributions. Apparently, there are huge cross-sectional differences in the regional patent performance. Whereas the least innovative regions count $3-12$ patents per 1,000 workers per year between 1994 to 2008 on average, the most innovative regions score as much as $58-218$ patents per 1,000 workers. Moreover, these innovation hubs are mainly located in the southern part of West Germany and West German cities such as Duesseldorf, Aachen, Frankfurt, Darmstadt and Heidelberg. In contrast, only a few East German cities such as Jena, Dresden and Berlin seem halfway competitive in the production of knowledge.

Figure 1p reveals a large demographic divide between German regions that appears to be highly negatively correlated to regional differences in innovative performance. In particular, the East German workforce is almost two years older on average than the West German workforce, indicating that plant closures and out-migration of young workers after reunification strongly affected the age structure of the East German labour force.7 Beyond the simple East-West

\footnotetext{
${ }^{6}$ For the classification of creative professionals and bohemians, we follow Möller and Tubadji (2009), see Appendix A.1

7 Burda and Hunt (2001) and Hunt (2004) provide empirical evidence for age-selective migration patterns of East-West migration after reunion and discuss the corresponding reasons. A more general approach is taken by Arntz et al. (2014) who define skills as a set of observable characteristics including education and age-related skills of workers and show that Eastern Germany experienced a net loss of such skills during the years between 1995-2008.
} 
Figure 1: Workforce age and patent activity by labour market regions (1994-2008)

(a) Number of patents per 1000 worker

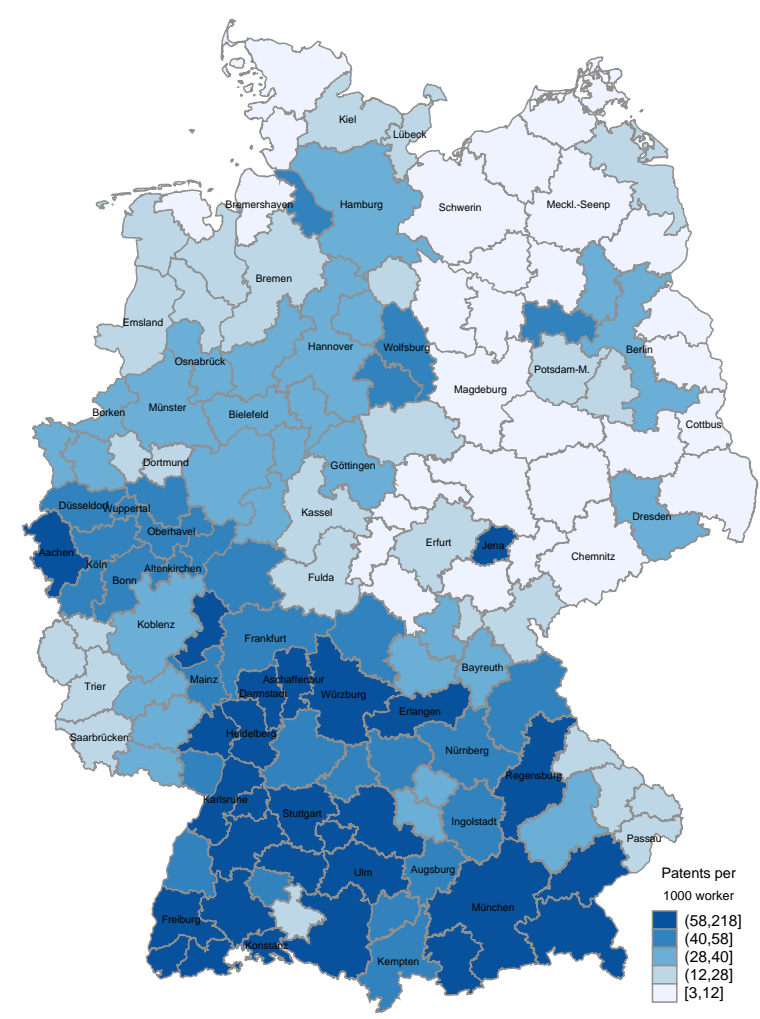

(b) Average workforce age

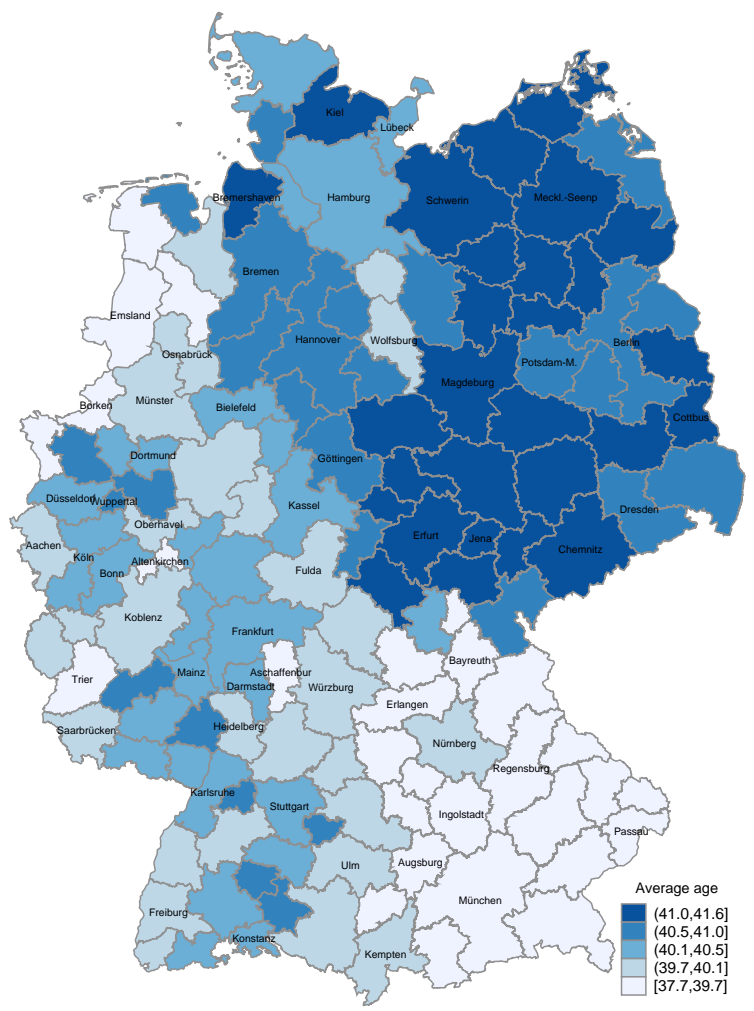

divide, the demographic landscape also seems to reflect an urban-rural divide with many urban areas in West Germany being older than the countryside. Overall, we find substantial regional variation in both the age and innovation dimension that appears to be negatively correlated. More precisely, a scatterplot for the average workforce age and the average patent count in Figure 2 suggests an inversely hump-shaped age-innovation profile when fitting a quadratic relationship with East German regions concentrating at the downward sloping part of the curve.

Of course, the descriptive relationship between workforce age and innovative performance at the regional level may well be driven by other characteristics. Table 1 thus contains summary statistics for important control variables by regional patent performance. In particular, we distinguish between the least innovative quintile of all regions and the most innovative quintile and show mean characteristics for these quintiles as well as the respective differences. Whereas the most innovative regions generated, on average, 90.4 patents per 1000 workers, the least innovative regions contributed only 7.7 patents. At the same time, the respective mean age differential between the regional workforces is around one year. More precisely, innovative regions have a higher share of young, but a lower share of middle-aged and especially older 
Figure 2: Scatterplot between average workforce age and patent production, average values for 1994-2008

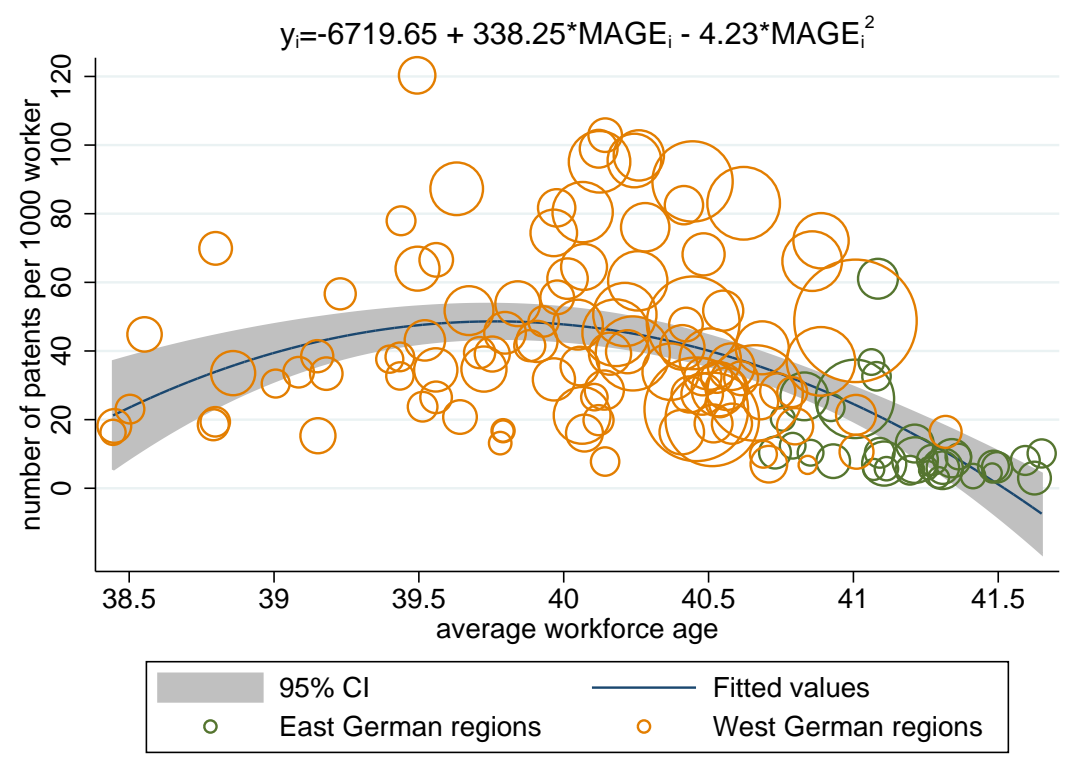

Notes: The size of the bubbles are proportional to population density. The shaded area represents the $95 \%$ confidence interval.

workers compared to the least innovative regions. In addition, the innovative regions also seem to be more age heterogeneous as measured by the age dispersion of the regional workforce.

The huge patent gap is, however, not only correlated with the regional workforce age, but also coincides with other well-known drivers of innovation. For instance, the most innovative regions exhibit approximately a twentyfold of private and a fourfold of public R\&D expenditures compared to the least innovative regions. Moreover, innovative regions are characterized by a larger workforce, higher population densities and larger shares of creative professionals. Interestingly, innovation hubs show larger shares of both high- and low-skilled workers, but lower shares of medium skilled workers. This might reflect a technology-induced job polarisation as has recently been argued by the task-based literature (Autor et al., 2003).

Adding such controls to our specification of interest, however, will not necessarily ensure the exogeneity of our regressor of interest, the regional age structure. First of all, there may be other time-constant or time-varying omitted variables. Secondly, reversed causality is of major concern since innovative regions might attract young workers. The East-West divide in both demographics and innovative performance might well reflect this inverse link. The following section thus discusses the methodological approach that addresses these concerns and allows for identifying the causal age-innovation link. 
Table 1: Summary statistics for German labour market regions, 1994-2008

\begin{tabular}{|c|c|c|c|c|c|}
\hline Variable & $\begin{array}{l}\text { All } \\
\text { regions } \\
\text { (1) }\end{array}$ & $\begin{array}{l}\text { Least } \\
\text { innovative } \\
\text { regions }^{\mathrm{a}} \\
(2)\end{array}$ & $\begin{array}{c}\text { Most } \\
\text { innovative } \\
\text { regions }^{\mathrm{a}} \\
(3)\end{array}$ & $\begin{array}{l}\text { Difference } \\
(3)-(2) \\
(4)\end{array}$ & $\begin{array}{c}\text { Data } \\
\text { Source }^{b}\end{array}$ \\
\hline number of patents & 155.77 & 15.52 & 359.94 & 344.41 & EPO \\
\hline number of patents per 1000 worker & 40.26 & 7.74 & 90.40 & 82.66 & $\mathrm{EPO}$ \\
\hline average workforce age & 40.29 & 41.18 & 40.05 & -1.13 & SIAB \\
\hline workforce age dispersion & 10.35 & 10.15 & 10.50 & 0.35 & SIAB \\
\hline share of workers aged $18-29$ (in \%) & 18.05 & 15.37 & 18.95 & 3.58 & SIAB \\
\hline share of workers aged $30-49$ (in \%) & 60.02 & 60.62 & 59.25 & -1.37 & SIAB \\
\hline share of workers aged 50 plus (in \%) & 21.93 & 24.01 & 21.80 & -2.21 & SIAB \\
\hline private RaD expenditures (in 1000 Euro) & 243.92 & 27.35 & 588.24 & 560.89 & GST \\
\hline public RaD expenditures (in 1000 Euro) & 135.19 & 47.72 & 210.90 & 163.19 & DeStatis \\
\hline share of creative professionals (in \%) & 5.16 & 3.72 & 6.32 & 2.60 & SIAB \\
\hline share of bohemians (in \%) & 0.68 & 0.65 & 0.76 & 0.11 & SIAB \\
\hline share of high-skilled workers (in \%) & 5.83 & 6.38 & 6.86 & 0.48 & SIAB \\
\hline share of medium-skilled workers (in \%) & 82.70 & 88.66 & 78.99 & -9.67 & SIAB \\
\hline share of low-skilled workers (in \%) & 11.47 & 4.96 & 14.15 & 9.19 & SIAB \\
\hline workforce size (in 1000) & 3.42 & 2.10 & 4.01 & 1.91 & SIAB \\
\hline population density (population per $100 \mathrm{~km}^{2}$ ) & 444.98 & 277.39 & 516.60 & 239.20 & DeStatis \\
\hline number of regions & 141 & 28 & 28 & 28 & \\
\hline
\end{tabular}

${ }^{a}$ Most (least) innovative regions are defined as regions in the highest (lowest) quintile of the regional innovation (per 1000 worker) distribution.

${ }^{\mathrm{b}}$ EPO: European Patent Office, SIAB: Sample of Integrated Labour Market Biographies released by German Federal Employment Agency, DeStatis: Regional database released by Federal Statistical Office, GST: German Stifterverband (Innovation Agency for the German science system)

\section{$5 \quad$ An IV approach to estimating the regional knowledge function}

As briefly discussed in the previous section, only exploiting the cross-sectional variation in our data runs the risk of biases from both time-varying and time-constant omitted variables as well as reversed causality. However, even when exploiting our yearly panel for the period 1994 to 2008 , the approach only allows for unobserved time-constant regional heterogeneity so that estimates continue to be biased due to the remaining sources of endogeneity. Moreover, reverse causality is likely to be more severe in the panel dimension. The reason is that the age structure of the workforce that we observe at any given point in time always results from two distinct forces: migration and natural population movements (new cohorts entering and exiting the labour market). To the extent that the regional age structure is inherited from the past due to past economic shocks that are not related to the contemporary innovation activity, but that still affect the contemporary age structure, the reversed causality should be less of a concern. In contrast, changes in the regional age structure over time are more likely to be determined by endogenous forces such as migration. Hence, as suggested by Brunow and Hirte (2006), 
one approach to mitigate the endogeneity of the age structure is to exploit the cross-sectional variation, since interregional differences in the age structure mainly reflect differences in the age structure of the non-migrant workforce. The advantage of the cross-sectional estimation is that it might be less biased by the endogeneity of (period-wise) migration than a panel approach. On the other hand, any cross-sectional variation may reflect unobserved regional heterogeneities.

Irrespective of whether using a cross-sectional or panel estimation approach, identifying the causal impact of the regional workforce age structure on innovative performance calls for an IV approach in order to mitigate the endogeneity of the regressor of interest. However, instrumenting the age structure in the panel context necessitates a time-varying set of instruments, which is more demanding in the panel than in the cross-sectional context. For all these reasons, we consider a cross-sectional IV regression to be our preferred specification as long as strong and valid instruments can be found. In particular, we consider the following three types of instruments to affect the contemporary age structure of the regional workforce, but to be plausibly exogenous in the innovative performance equation conditional on further controls such as public and private R\&D investments, regional industry mix, workforce size, population density and the skill mix of the regional workforce:

1. The historical youth-population-ratio refers to the share of individuals aged 0 to 18 years among the population in region $i$ aged between 0 to 45 years in 1985 as given by the German Statistical Office. This instrument captures the share of individuals that enters the labour market during our observation period and may thus affect the regional workforce age structure. In particular, the higher this youth-population-ratio, the younger should be the regional workforce age. At the same time, we consider this instrument to be unrelated to today's innovative performance since we assume most of these children and teenagers to be born in region $i$ between 1967 and 1985 as families tend to move within local labour markets only (Kulu, 2008). Hence, economic shocks that induced their parents to move to region $i$ before the birth of the first child probably occurred between 1960 to 1980 and are likely to be unrelated to current innovative performance given the structural changes since the late 1970s and 1980s in the aftermath of the oil crises.

2. The historical share of bohemians corresponds to the share of individuals that can be considered to be bohemians (e.g. artists, musicians, publishers) among the local workforce as computed from the SIAB data for 1985. The idea behind this instrument stems from 
the discussion in Florida (2002) who suggests that the localization of the bohemian class is often driven by factors unrelated to economic growth or regional innovative performance, but may than trigger an inward migration of (mostly young) professionals ${ }^{8}$ In line with this research, we assume that the size of the bohemian class 20 years ago rejuvenates the regional workforce 20 years later and is also orthogonal to current innovation output.

3. The historical public sector share as measured by the share of public sector workers in 1985 based on the SIAB data, is unlikely to be related to today's innovative performance since the localization of public sector jobs is usually driven by administrative considerations. At the same time, these jobs are typically considered to be particularly familyfriendly and thus highly attractive for female workers. In fact, with females increasing their labour force participation throughout the 1970s and 1980s, many women actually entered the public sector. Between 1979 and 2008, for example, the share of women in the public sector in the SIAB data increased from $44.8 \%$ to $58.7 \%$. We therefore assume public sector hubs to attract young women, thus affecting the regional rate of family formation and, hence, fertility. As a consequence, public sector hubs in 1985 should have a younger workforce twenty years later.

As previously discussed, we will apply these instruments in a cross-sectional estimation of the age-innovation link. However, since the latter two instruments are available for West Germany only, we restrict our main estimations to West Germany. In particular, we estimate two different specifications of the regional production of knowledge:

[A] Knowledge production function quadratic in age. For ease of comparison with much of the literature on age-productivity effects, we begin by estimating the regional patent performance as a quadratic function of the regional workforce age. More precisely, we estimate the following OLS-model for a cross-section of regions where all variables are defined as the average values between 1994 and 2008

$$
\ln P_{i}=\alpha+\gamma_{1} M A G E_{i}+\gamma_{2} M A G E_{i}^{2}+\delta \mathbf{S}_{i}+u_{i}
$$

with $\ln P_{i}$ as the $\log$ of the regional patent count in region $i, M A G E_{i}$ as the mean age of the regional workforce, and $\mathbf{S}_{i}$ as a vector of controls including public and private $\mathrm{R} \& \mathrm{D}$ expenditures,

\footnotetext{
${ }^{8}$ One example for such a mechanism is Berlin, see Moretti (2012).
} 
the number of creative professional 9 population density, the structure of the regional industry base measured by the regional employment share of 16 industries and the size of the workforce. When running the estimation for both East and West Germany, we add a dummy for East Germany.

We also run robustness checks for a sample of East and West German regions, but have to restrict the IV set to historical population instruments since our other historical instruments are available for West Germany only. Moreover, we test if our results are robust against using panel estimations by collapsing our yearly data to a panel of five periods, each comprising the average regional value across three years $\left(t_{1}: 1994-1996, t_{2}: 1997-1999, t_{3}: 2000-2002\right.$, $\left.t_{4}: 2003-2005, t_{5}: 2006-2008\right)$. We do so because the yearly patent activity appears to be strongly varying on a yearly basis whereas changes in the age structure are much more persistent. For this reason, we aggregate three years to one period and allow for a lag between the output and the input measure of one period. We then estimate Equation (6) by adding region fixed effects and period dummies. We instrument the endogenous $M A G E_{i}$ variable by the same set of instruments lagged by three periods, i.e. the mean workforce age between 1994 to 1996, for example, is instrumented by the IV set for 1985-1987. However, the link between these instruments and the change in the regional demographic composition across time is likely to be weaker than in the cross-sectional context.

[B] Translog knowledge production function. Since the use of a quadratic age-innovation link is rather restrictive, we alternatively estimate the Translog production function described in Section 2. Compared to Equation (6), we use the number of young (18-39), middle-aged (30-49) and older workers (50 plus), its squared terms and interactions. In particular, we estimate the following cross-sectional model again using average values for the period 1994 to 2008:

$$
\begin{aligned}
\ln P_{i}= & \alpha+\gamma_{1} \ln A_{1, i}+\gamma_{2} \ln A_{2, i}+\gamma_{2} \ln A_{3, i}+\gamma_{3} \ln A_{1, i}^{2}+\gamma_{4} \ln A_{2, i}^{2}+\gamma_{5} \ln A_{3, i}^{2} \\
& +\gamma_{6}\left(\ln A_{1} \times \ln A_{2}\right)_{i}+\gamma_{7}\left(\ln A_{1} \times \ln A_{3}\right)_{i}+\gamma_{8}\left(\ln A_{2} \times \ln A_{3}\right)_{i}+\delta \mathbf{S}_{i}+\epsilon_{i}
\end{aligned}
$$

where $A_{1}, A_{2}$ and $A_{3}$ represent our three age groups, and $\mathbf{S}_{i}$ is a set of controls as defined before except for leaving out workforce size since the size effect is already captured by the sum of our

\footnotetext{
${ }^{9}$ Alternatively, we used the share of high-skilled workers with a tertiary education, but found only insignificant effects. In fact, the share of creative professionals turned out to be a much more important driver of innovative performance than the level of the formal education.
} 
three age groups. With the the three age groups and all its quadratic and interactions terms being endogenous, the IV set as described above does not suffice since we need at least nine instruments for identification. We therefore split up the historical youth-population ratio into five subgroups including the share of $0-3,3-6,6-10,10-15$ and $15-18$ among the total population in region $i$ aged between 0 and 45 years to allow for more heterogeneity that may affect the share of young, middle-aged and older workers. In fact, the share of 50 plus workers should be driven by the share of the population in middle ages in 1985. For this reason, we further add the share of those aged 18-20, 20-25, 25-30, 30-35, 35-40 and 40-45 in 1985. Of course, for these older workers in 1985, the exogeneity may be more problematic than for the underaged population, but we calculate Hansen j-statistics to get some insights on the validity of the instruments. Also, we add the historical interactions of the share of underaged (0-18), the young (18-30) and the middle-aged (30-45) population that are likely to affect the interacted worker shares in our Translog specification. In addition to the historical population age structure, we complement the IV set with the share of bohemians and the share of public sector jobs as of 1985 . We thus have a total of 16 instruments for nine endogenous variables.

\section{$6 \quad$ Estimation results}

\subsection{Age-innovation profile}

Table 2 shows the estimates for Equation (6) for West Germany using regional averages for the period 1994 to 2008. Column (1) shows a basic OLS specification with R\&D investments, and human capital characteristics only. We then add controls for workforce size, industry shares and agglomeration as measured by population density (Column 2). Columns (3)-(4) use the same set of controls and instrument the mean workforce age and its squared term as described in the previous section. While Column (3) reports the Two Stage Least Squares (2SLS) estimates, the IV regression in Column (4) uses Limited Information Maximum Likelihood (LIML).

First of all, note that our model is able to replicate standard findings of the literature. We find a positive and significant elasticity for private sector $R \& D$ expenditures in the range of 0.28-0.38 and an insignificant impact of public R\&D investments. This is consistent with other studies on the German regional innovation system. Fritsch and Slavtchev (2007), for example, estimate a random effects panel model and report elasticities of private sector $\mathrm{R} \& \mathrm{D}$ between 0.17 and 0.22 , whereas the impact of public R\&D is only small. As expected also, the number 
Table 2: Cross-sectional estimates for West German regions

\begin{tabular}{|c|c|c|c|c|}
\hline \multirow[t]{2}{*}{ Dependent variable: number of patents $(\log )$} & \multicolumn{2}{|c|}{ OLS } & \multicolumn{2}{|c|}{ IV } \\
\hline & (1) & $(2)$ & $\begin{array}{l}\text { 2SLS } \\
(3)\end{array}$ & $\begin{array}{l}\text { LIML } \\
(4)\end{array}$ \\
\hline \multicolumn{5}{|l|}{ R\&D INPUTS } \\
\hline private R\&D exp. (log, in 100 tsd Euro) & $\begin{array}{c}0.38^{* * *} \\
(5.77)\end{array}$ & $\begin{array}{c}0.30 * * * \\
(5.25)\end{array}$ & $\begin{array}{c}0.28^{* * *} \\
(4.35)\end{array}$ & $\begin{array}{c}0.28^{* * *} \\
(3.86)\end{array}$ \\
\hline public R\&D exp. (log, in 100 tsd Euro) & $\begin{array}{l}-0.00 \\
(-0.05)\end{array}$ & $\begin{array}{c}0.01 \\
(0.27)\end{array}$ & $\begin{array}{c}0.02 \\
(0.66)\end{array}$ & $\begin{array}{c}0.03 \\
(0.67)\end{array}$ \\
\hline \multicolumn{5}{|l|}{ HUMAN CAPITAL INPUTS } \\
\hline average workforce age & $\begin{array}{c}17.13^{* * *} \\
(3.42)\end{array}$ & $\begin{array}{c}19.47^{* * *} \\
(4.17)\end{array}$ & $\begin{array}{l}65.58 \\
(1.42)\end{array}$ & $\begin{array}{l}74.31 \\
(1.26)\end{array}$ \\
\hline average workforce age (squared) & $\begin{array}{c}-0.22^{* * *} \\
(-3.43)\end{array}$ & $\begin{array}{c}-0.25 * * * \\
(-4.18)\end{array}$ & $\begin{array}{c}-0.83 \\
(-1.42)\end{array}$ & $\begin{array}{c}-0.94 \\
(-1.27)\end{array}$ \\
\hline num. of creative professionals (log) & $\begin{array}{c}0.57^{* * *} \\
(5.27)\end{array}$ & $\begin{array}{c}0.22 \\
(0.70)\end{array}$ & $\begin{array}{c}-0.20 \\
(-0.42)\end{array}$ & $\begin{array}{l}-0.28 \\
(-0.48)\end{array}$ \\
\hline \multicolumn{5}{|l|}{ REGIONAL INDICATORS } \\
\hline population density (log) & & $\begin{array}{c}0.22 * * \\
(2.26)\end{array}$ & $\begin{array}{l}0.47^{*} \\
(1.92)\end{array}$ & $\begin{array}{l}0.51^{*} \\
(1.70)\end{array}$ \\
\hline workforce size (log, in tsd) & & $\begin{array}{c}0.37 \\
(1.22)\end{array}$ & $\begin{array}{c}0.73 \\
(1.60)\end{array}$ & $\begin{array}{c}0.79 \\
(1.50)\end{array}$ \\
\hline constant & $\begin{array}{c}-339.58^{* * *} \\
(-3.41)\end{array}$ & $\begin{array}{c}-394.12^{* * *} \\
(-4.25)\end{array}$ & $\begin{array}{c}-1303.39 \\
(-1.42)\end{array}$ & $\begin{array}{c}-1476.46 \\
(-1.27)\end{array}$ \\
\hline With industry shares? & no & yes & yes & yes \\
\hline $\mathrm{N}$ & 108 & 108 & 108 & 108 \\
\hline R-squared & 0.911 & 0.951 & 0.895 & 0.873 \\
\hline $\mathrm{F}$ & 258.5 & 154.8 & 57.4 & 48.8 \\
\hline Hansen (j-statistic) & & & 0.420 & 0.367 \\
\hline Hansen (p-value) & & & 0.517 & 0.545 \\
\hline
\end{tabular}

Notes: t-statistics in parentheses $* \mathrm{p}<0.10, * * \mathrm{p}<0.05, * * * \mathrm{p}<0.01$. Standard errors are clustered by region. First stage regressions are shown in Appendix A.2.

of creative professionals has a positive sign in Column (1). Although, the share of creative professionals seems to be strongly related to the regional industry mix and the urban density. Once we control for these factors in Column (2), the positive coefficient for creative professionals becomes insignificant.

Regarding the main variables of interest, we find a positive and significant impact of the regional workforce age on innovative performance in the OLS specifications (Columns 1-2). In fact, the coefficients suggest a hump-shaped age-innovation link with a maximum patent activity in regions with a workforce aged 38.9 on average. However, when instrumenting the workforce age in Column (3), the impact turns insignificant, suggesting that the age effect may be driven by endogenous forces. The instruments thereby have the expected signs in the first stage, compare Appendix A.2. In particular, the past youth population ratio, the past share of bohemians and the past public sector share have the expected negative and significant signs. Despite the significance of the instruments, the F-Test of excluded instruments is below the rule-of-thumb 
value of 10. We therefore follow Angrist and Pischke (2009) and re-estimate the model using LIML in Column (4), which is known to be more robust to weak instruments. The estimation parameter do not vary much between 2SLS and LIML though. Also, the Hansen J-statistics suggest that our instruments are valid.

Both IV estimates indicate that the hump-shaped age-innovation profile that we find both descriptively in Section 4 and in the OLS estimates in Table 2 is driven by endogenous forces. For comparison, we also exploit the panel dimension of our data and compare pooled estimates to a model with region fixed effects both with and without instrumenting the workforce age as described in Section $5{ }^{10}$ According to the estimates in Appendix A.3, the age-innovation link disappears when controlling for unobserved time-constant factors in the fixed effects estimation, irrespective of whether applying an IV strategy or not 11 In fact, the weak overall explanatory power of the fixed effects model suggests that the regional innovation system and the regional age structure are not changing sufficiently for identifying the effects. Therefore, we think that it is more suitable to exploit the cross-sectional variation across regions that can be instrumented by long lags of the regional population and the other workforce measures.

In addition, we compare our estimates from Table 2 to an extended sample that also includes East Germany (see Appendix A.4 12 In line with our previous estimates, the age-innovation link is similar in the OLS specification, but turns insignificant when using the IV approach. Finally, our estimates also appear robust against using the number of citations of the regional patents rather than the patent count as an alternative outcome measure (see Appendix A.3.

Overall, our estimates based on a knowledge production function with a quadratic specification do not confirm the creativity-diminishing effect of an aging workforce that has been suggested by many individual- and firm-level studies. Our results rather suggest that the descriptive hump-shaped profile is partly driven by endogenous forces and reverse causality. However, the simple quadratic specification might be too restrictive for a more complex age-related innovation effect. In fact, knowledge interactions between different age groups might take place both within and across firms and could be partially compensating for an age-related decline in cognitive and mental capacities. We therefore investigate the age-innovation link in a more

\footnotetext{
${ }^{10}$ Note that we loose one of the five periods for the estimation since our output measure is defined as the number of patents in period $t+1$. This leaves us with four periods and $4 \times 108=432$ observations.

${ }^{11}$ The Hansen Test of valid instruments cannot be rejected for the FE-IV model. Also, the corresponding first stage estimates suggest relevant instruments (F-statistics above 10).

${ }^{12}$ As previously discussed, we only have the lagged population structure for instrumenting the mean workforce age when including East German regions in the sample.
} 
flexible way in the subsequent section.

\subsection{Age Complementarities}

As a much more flexible alternative to the quadratic specification chosen above, we estimate a Translog knowledge production function ${ }^{13}$ as discussed in Sections 2 and 5 to allow for the possibility that the marginal productivity of one age group actually benefits from the presence of another age group. This might be the case if age-specific strength's turn out to complement each other as could be the case between higher cognitive abilities in younger ages and professional experience and networks of older workers.

OLS and IV estimates for the Translog knowledge production function from Equation (7) are shown in Appendix A.6. We stick to the cross-sectional analysis as our main specification for reasons laid out above. Also, we again restrict the sample to West German regions since we have a stronger set of instruments available for this part of the country 14 The first stages for these endogenous variables all indicate a strong IV set with F-statistics (of excluded instruments) ranging between 15 and 68.9 15 Moreover, the Hansen j-statistics strongly suggest that our instruments are valid. We are thus confident that we have both a strong and an exogenous IV set. Based on the OLS and the IV coefficients, we then calculate the marginal products of each age group with respect to the generation of patents (denoted $\mu_{1}, \mu_{2}$ and $\mu_{3}$ ), the second order derivatives (denoted $\sigma_{11}, \sigma_{22}$ and $\sigma_{33}$ ) as well as the cross-partial derivatives between the three labour inputs (denoted $\sigma_{12}, \sigma_{13}$ and $\sigma_{23}$ ). The estimated structural parameters are summarized in Table 3 . Note that the marginal products correspond to the effect of extending a particular age group by 100 workers on the number of regional patents while keeping all other input factors constant. The second order derivatives correspond to the change in the marginal product of an input factor with the level of that input. Similarly, the cross-partial derivative, $\sigma_{j k}$, refers to the change in the marginal product of age group $j$ due to 100 additional workers of age group $k$. Note that $\sigma_{j k}$ equals $\sigma_{k j}$ in our production function.

\footnotetext{
${ }^{13}$ In fact, the most flexible production technology would be a CES-Translog functional form. We therefore ran tests whether the more restrictive CES, Translog or Cobb-Douglas production functions are nested in the CES-Translog technology. For Cobb-Douglas and CES, the tests wer rejected, whereas the Translog production technology seems to approximate the more flexible form quite well, see Appendix A.5.

${ }^{14}$ We ran a number of robustness checks, see Appendix A.7 When re-estimating the model based on a sample including East and West German regions, we get quite similar results for the OLS model, but get implausible estimates for the IV model. This likely reflects that we have to drop the historical shares of bohemians and public sector jobs in the IV set when including East German regions, resulting in a much weaker instrument set. When using the number of citations as an alternative outcome measure for a sample of West German regions, however, we get similar results than before.

${ }^{15}$ First stage results are available from the authors upon request.
} 
Table 3: Structural estimates of marginal products, second order and cross-partial derivatives from Equation 5 (West-Germany)

\begin{tabular}{lcc}
\hline Dependent variable in Translog model: number of patents $(\mathrm{log})$ & \\
& OLS & IV \\
& $(1)$ & $(2)$ \\
\hline predicted patents & $196.61^{* * *}$ & $203.36^{* * *}$ \\
& $(8.26)$ & $(7.44)$ \\
MARGINAL PRODUCTS $(\mathrm{N}=108)$ & & \\
young workers $\left(\mu_{1}\right)$ & $1.26^{* * *}$ & 1.43 \\
& $(3.39)$ & $(1.60)$ \\
middle-aged workers $\left(\mu_{2}\right)$ & -0.16 & 0.10 \\
& $(-1.21)$ & $(0.24)$ \\
older workers $\left(\mu_{3}\right)$ & -0.34 & -0.92 \\
& $(-1.25)$ & $(-1.21)$ \\
\hline SECOND ORDER DERIVATIVES $(\mathrm{N}=108)$ & & \\
young workers $\left(\sigma_{11}\right)$ & -0.00 & 0.03 \\
& $(-0.13)$ & $(1.55)$ \\
middle-aged workers $\left(\sigma_{22}\right)$ & 0.00 & 0.00 \\
& $(0.78)$ & $(1.02)$ \\
older workers $\left(\sigma_{33}\right)$ & -0.01 & -0.03 \\
& $(-0.71)$ & $(-1.07)$ \\
\hline CROSS-PARTIAL DERIVATIVES $(\mathrm{N}=108)$ & & \\
young and middle-aged workers $\left(\sigma_{12}\right)$ & -0.00 & $-0.02^{* * *}$ \\
young and older workers $\left(\sigma_{13}\right)$ & $(-1.40)$ & $(-2.87)$ \\
& $0.01^{*}$ & $0.03^{* *}$ \\
& $(1.91)$ & $(2.06)$ \\
& -0.00 & 0.00 \\
& $(-0.29)$ & $(0.21)$ \\
\hline
\end{tabular}

Notes: The table presents estimates at the mean of the sample. t-statistics in parenthesis; calculated based on Delta-method; significance levels: $* \mathrm{p}<0.10$, ${ }^{* *}$ $\mathrm{p}<0.05,{ }^{* * *} \mathrm{p}<0.01$. Coefficients reflect absolute increases per 100 additional workers. The corresponding Translog estimates are displayed in Appendix A.6.

Consistent with the previous section, neither OLS nor IV estimates suggest a significant hump-shaped pattern for the age-specific marginal products. Our results rather speak in favour of a more complex pattern although establishing significance for the parameters proves difficult with a sample size of only $N=108$. In particular, our findings weakly suggest that younger workers boost regional patent activities. According to our estimates, 100 additional workers aged below 30 years increases the patents generated at the regional level by about 1.3 to 1.4 , although the effect marginally misses significance in the IV model. The second order derivative $\sigma_{11}$ is positive which would indicate an increase in this marginal effect with the size of the younger workforce, but, again, the parameter misses significance. For older workers we cannot find a significant negative marginal product on the generation of knowledge. The results are also reflected in Figure 3 which plots the age-group-specific marginal effects on regional patenting. 
Figure 3: Predicted marginal effects on patent performance by the size of the younger, middleaged and older workforce.
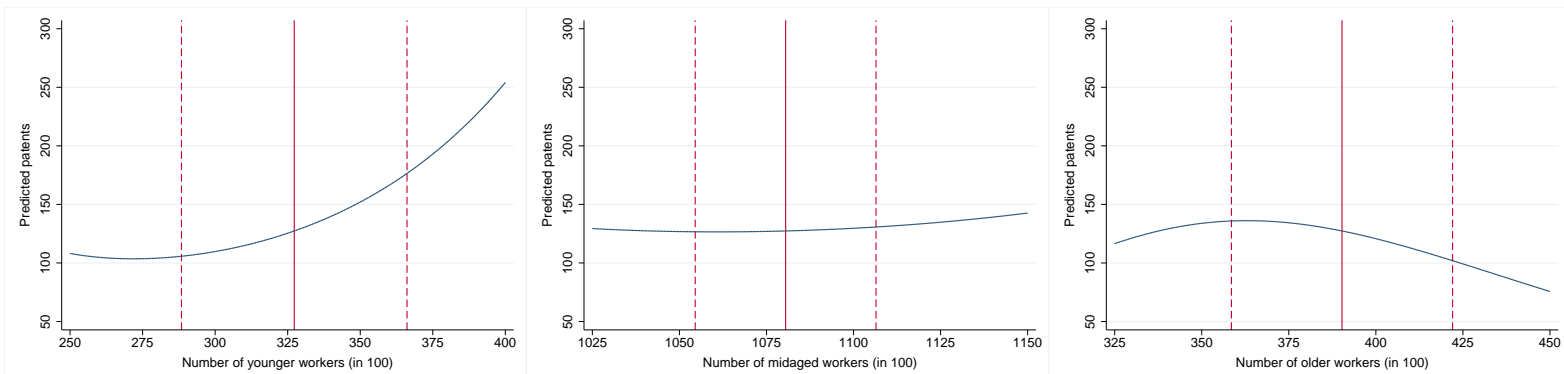

Notes: Prediction based on estimates from IV-Translog specification for West Germany shown in Appendix A.6. The solid red line marks the mean size of the workforce and the dashed lines capture $+/-1$ standard deviation in the share of the respective age group.

The graphs correspond to the predicted effect of each of the three age groups on innovation performance while holding the size of the two other age groups constant at the mean. Not surprisingly given the above estimates, we find a rather flat impact of the size of the middleaged workforce and a slightly inversely U-shaped pattern for older workers. A sizeable and monotonously increasing effect on patenting only comes from younger workers.

Interestingly, part of this positive marginal effect of a young talent pool results from significant complementarities with older workers. As suggested by $\sigma_{13}$ based on the IV estimates (see Table 3), an increase in the number of older (younger) workers by 100 significantly increases the marginal productivity of younger (older) workers by 0.03 units. The two groups thus boost each others productivity which likely reflects the complementarity of age-specific skills and experiences. The impact of younger workers on regional patenting thus also hinges on the presence of an experienced older workforce. Furthermore, we find some interdependencies between younger and middle-aged workers that indicate a substitutability of these age groups in the invention process. Apparently, these two groups are too similar in skills and experience to benefit from each other.

Simulating patent counts for varying labour inputs. In order to gain more insights into how the detected complementarities between younger and older workers affect the regional production of knowledge, Figure 4 plots patent performance as a function of the two labour inputs, holding the size of middle-aged workers constant at the mean. With the current mean region having around 30,000 young and 38,000 older workers, the current mean region is located in the middle of the graph. There are several things worth noting from this three-dimensional plot. 
Figure 4: Simulated patent counts for varying inputs of young and older workers

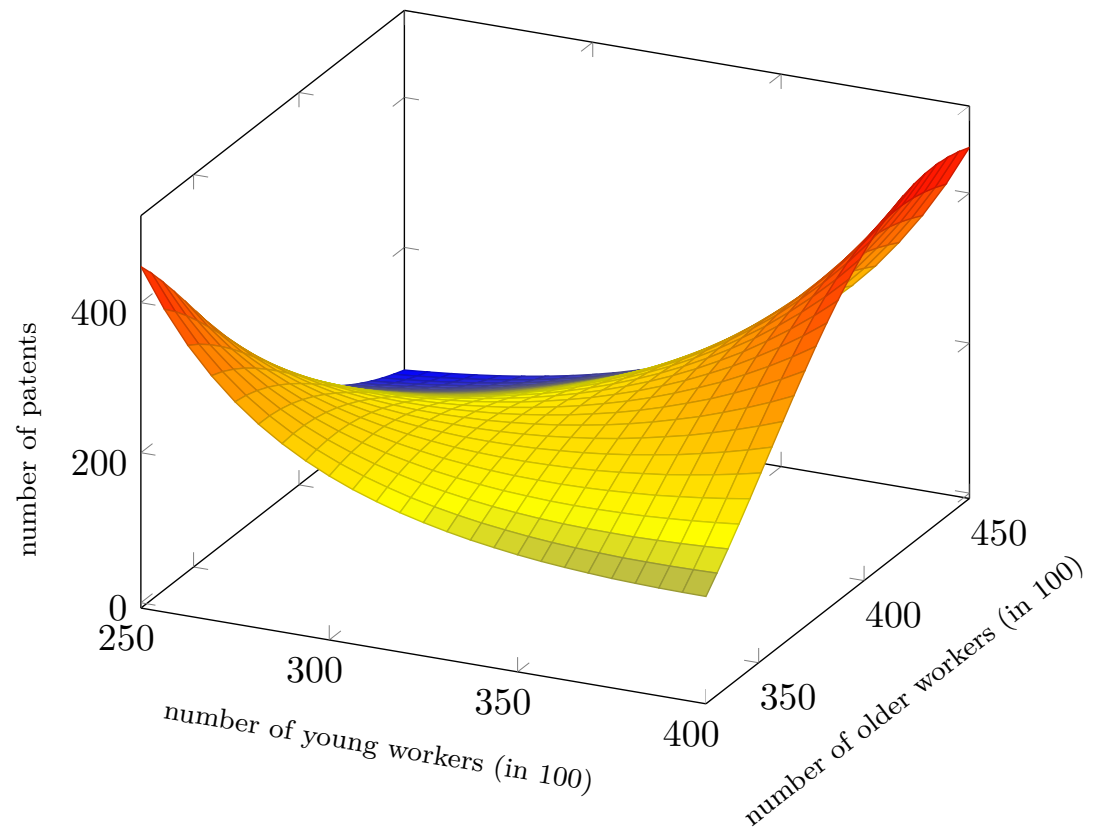

Notes: The figure plots patent performance as a function of both young and older workers, holding the size of middle-aged workers constant at the mean. Simulations are based on estimates from IV-Translog specification for West Germany shown in Appendix A.6

First of all, despite the young worker base having a positive marginal impact on regional innovative performance on average, as shown in Table 3 , an additional younger worker may even reduce the regional performance if the number of older workers is very low and the negative impact on the marginal productivity of the middle-aged population dominates the positive complementing effect between younger and older workers. With increasing numbers of older workers, however, the marginal effect of younger workers turns positive and even increases sharply for regions with a large amount of elderly. Put differently, regional innovations hinge on the abilities of younger ages, but these abilities need to be complemented by a sufficient amount of experience in order to boost innovations.

As a second observation from the graph, consider the likely movement in the plane that goes along with demographic aging. In fact, for the time period 1994 to 2008 for which we have data available, the share of middle-aged workers did not change in the average German region. At the same time, the share of workers below the age of 30 dropped by around $6 \%$ while the share of 50 plus workers increased by $6 \%$ in the average region. Hence, aging is likely to correspond to a movement towards the angle in the back of Figure 4 a situation that is clearly characterized by low productivity in terms of innovative outcomes. The problem is not so much the increasing 
Table 4: Observed, predicted and simulated performance gap between least and most innovative regions with counterfactual age structures

\begin{tabular}{llccc}
\hline & & $\begin{array}{c}\text { Least } \\
\text { innovative } \\
\text { regions }\end{array}$ & $\begin{array}{c}\text { Most } \\
\text { innovative } \\
\text { regions }\end{array}$ & Patent gap \\
& & $(1)$ & $(2)$ & $(2)-(1)$ \\
\hline (A) & observed patents & 15.52 & 359.94 & 344.41 \\
(B) & predicted patents & $52.82^{* * *}$ & $397.52^{* * *}$ & 344.7 \\
& & $(5.68)$ & $(7.14)$ & \\
(C) & simulated patents & $111.75^{* * *}$ & $397.52^{* * *}$ & 285.77 \\
& (assuming age structure of most innovative regions) & $(2.83)$ & $(7.14)$ & \\
(D) & simulated patents & $52.82^{* * *}$ & $336.77^{* * *}$ & 283.95 \\
& (assuming age structure of least innovative regions) & $(5.68)$ & $(5.58)$ & \\
\hline
\end{tabular}

Notes: The table predicts patent performance for the mean characteristics of the least and most innovative regions as shown in Table 1. Simulation in Line C (D) predicts patents for the least (most) innovative regions using the age structure of the most (least) innovative region, keeping all other characteristics constant. Calculations are based on IV model in Appendix A.6. t-statistics in parenthesis; calculated based on Delta-method; significance levels: ${ }^{*} \mathrm{p}<0.10,{ }^{* *} \mathrm{p}<0.05,{ }^{* * *} \mathrm{p}<0.01$.

number of older workers per se, but the shrinking younger talent pool that may benefit from the experience of the older one.

Explaining the patent gap across German regions. To derive further implications of the estimated parameters for the German innovation divide, we now quantify to what extent differences in the age structure can explain the observed patent gap between the least and most innovative regions. For this purpose, Table 4 reports the observed (Line A), predicted (Line B) and simulated (Lines C and D) patent gaps. The simulated values thereby refer to counterfactual predictions for the least (most) innovative regions having the share of young, middle-aged and older workers equal to the most (least) innovative regions, holding other characteristics of the workforce constant. As Table 4 shows, the predicted total gap in patent performance amounts to 345 patents which is quite close to the observed gap (compare also Table 1). This predicted gap also contains the impact of the difference in the age structure. While the share of middle-aged workers is quite comparable across both types of regions, the most innovative regions have a share of younger workers of around $19 \%$ and a share of older workers of around $22 \%$ compared to $15 \%$ and $24 \%$ in the least innovative regions.

When adjusting the age structure in the least innovative regions to equal the structure of the most innovative regions, the predicted patent performance approximately doubles, see Line $(\mathrm{C})$. The remaining gap between the least and most innovative regions that are due to differences in all 
other characteristics, but hold the age structure constant, however, still amounts to 286 patents which is about $83 \%$ of the predicted gap in Line (B). Similarly, adjusting the age structure of the most innovative regions to reflect the shares that we observe in the least innovative regions, reduces the patent gap to 284 . Hence, if the least (most) innovative regions had the same age structure than the most (least) innovative German regions, the expected gap in innovative performance would be reduced by about $17 \%$. In terms of economic relevance, this is clearly a sizable impact that again stresses the policy relevance of our results.

\section{Conclusion}

This paper contributes to the debate on demographic aging in Europe and its potential effects on innovative capacity and regional disparities by evaluating the causal impact of workforce age structure on regional innovations. For the analysis, we estimate a regional knowledge production function quadratic in the mean age of the regional workforce similar to many previous studies on the age-productivity link and contrast this to a much more flexible Translog production technology that allows for complementarities and substitutability between different age groups. We thereby address potential endogeneity of the regional workforce by using long lags of regional demographics, the share of bohemians and the public sector share for an IV approach.

Overall, we do not find a creativity-diminishing effect for aging labour market regions in Germany in a simple production function with a quadratic specification once taking into account the potential endogeneity of the regional workforce. Hence, the hump-shaped age-innovation profile that is suggested descriptively and by our OLS estimates seems to be driven by endogenous forces. However, when using a more flexible Translog production function, a much more complex pattern is revealed. In particular, our results tentatively indicate that younger workers boost regional innovations, but that this effect partly hinges on the presence of older workers. Moreover, we find a significant complementarity between younger and older workers that may reflect that the cognitive abilities of younger ages and the experience of the older workforce complement each other in the production of knowledge. In contrast, younger and middle-aged workers seem to constitute substitutable input factors in the knowledge production technology. For the least and most innovative German regions, the difference in the age structure is able to explain around $17 \%$ of the gap in innovative performance suggesting that our findings are also economically relevant. 
For the demographic aging in Germany and many other western societies, these findings have important policy implications. First of all, our estimates show that up to some point, demographic aging need not have negative effects on knowledge creation. As long as there are sufficient numbers of younger workers, additional older workers may in fact induce positive effects on innovative performance at first. However, our findings indicate a declining knowledge production in the future if demographic aging further increases the size of the older workforce at the expense of the younger one. This is because it necessitates a sufficient size of the younger talent pool to benefit from the experience and innovation-enhancing effect of older cohorts. From this we can conclude that certain fears of decreasing creativity in aging societies appear to be justified. Counteracting effects of complementarities between younger and older workers are both economically relevant and significant, but do not seem to suffice to actually make up for the age-driven disadvantage in the generation of knowledge in case of a continued process of demographic aging.

Our findings stress the relevance of attracting the young talent from abroad. This is because innovations are likely to increasingly occur only in regions with a relatively high share of younger workers. In fact, from a policy perspective, it may be reasonable to support the development of young hubs as a potential nucleus for innovations. Finally, the complementarities between younger and older workers suggests that policy makers should focus on improving the conditions for an exchange across age groups both within and across firms. Nevertheless, further research is necessary to better understand the factors that favour strong age complementarities and that may counterbalance negative aging effects. For instance, the role of urban density and agglomeration economies in fostering knowledge exchange between different age cohorts may by exploited. Also, more general production functions may be modelled to identify further crosselasticities between demographic measures and innovation-enhancing factors such as R\&D, skills and the urban context. Finally, investigating the spatial heterogeneity of the effects may provide additional insights into how these demographic trends are shaping the spatial distribution of knowledge creation. 


\section{References}

Acs, Z., Anselin, L., and Varga, A. (2002). Patents and innovation counts as measures of regional production of new knowledge. Research Policy, 31(7):1069-1085.

Acs, Z. and Audretsch, D. (1990). Innovation and small firms. MIT Press.

Acs, Z., Audretsch, D., and Feldman, M. (1992). Real effects of academic research: comment. American Economic Review, pages 363-367.

Angrist, J. and Pischke, J.-S. (2009). Mostly harmless econometrics: An empiricist's companion. Princeton University Press.

Arntz, M., Gregory, T., and Lehmer, F. (2014). Can regional employment disparities explain the allocation of human capital across space? Regional Studies, forthcoming.

Audretsch, D. and Feldman, M. (1996). R\&D spillovers and the geography of innovation and production. American Economic Review, 86(3):630-640.

Audretsch, D. and Feldman, M. (2004). Knowledge spillovers and the geography of innovation. Handbook of Regional and Urban Economics, 4:2713-2739.

Autor, D. H., Levy, F., and Murnane, R. J. (2003). The skill content of recent technological change: An empirical exploration. Quarterly Journal of Economics, 118:4.

Backes-Gellner, U. and Veen, S. (2013). Positive effects of ageing and age diversity in innovative companies-large-scale empirical evidence on company productivity. Human Resource Management Journal, 23(3):279-295.

Bönte, W., Falck, O., and Heblich, S. (2009). The impact of regional age structure on entrepreneurship. Economic Geography, 85(3):269-287.

Börsch-Supan, A. and Weiss, M. M. (2011). Productivity and age: Evidence from work teams at the assembly line. Technical report, Munich Center for the Economics of Aging (MEA) at the Max Planck Institute for Social Law and Social Policy.

Bratsberg, B., Ragan Jr, J. F., and Warren, J. T. (2003). Negative returns to seniority: New evidence in academic markets. Industrial and Labor Relations Review, pages 306-323. 
Brunow, S. and Hirte, G. (2006). Age structure and regional economic growth. Jahrbuch für Regionalwissenschaft, 26(1):3-23.

Burda, M. C. and Hunt, J. (2001). From reunification to economic integration: Productivity and the labor market in Eastern Germany. Brookings Papers on Economic Activity, 32(2):1-92.

Cardoso, A. R., Guimarães, P., and Varejão, J. (2011). Are older workers worthy of their pay? An empirical investigation of age-productivity and age-wage nexuses. De Economist, 159(2):95-111.

Ceh, B. (2001). Regional innovation potential in the United States: Evidence of spatial transformation. Papers in Regional Science, 80(3):297-316.

Dostie, B. (2011). Wages, productivity and aging. De Economist, 159(2):139-158.

Feldman, M. (1999). The new economics of innovation, spillovers and agglomeration: A review of empirical studies. Economics of Innovation and New Technology, 8(1-2):5-25.

Feldman, M. P. and Florida, R. (1994). The geographic sources of innovation: Technological infrastructure and product innovation in the United States. Annals of the Association of American Geographers, 84(2):210-229.

Feyrer, J. D. (2008). Aggregate evidence on the link between age structure and productivity. Population and Development Review, 34:78-99.

Fischer, M. and Varga, A. (2003). Spatial knowledge spillovers and university research: Evidence from Austria. The Annals of Regional Science, 37(2):303-322.

Florida, R. (2002). The Rise oft he Creative Class and how its transforming work, leisure, community $\&$ everyday life. Basic Books. New York.

Fritsch, M. and Slavtchev, V. (2007). Universities and innovation in space. Industry \& Innovation, 14(2):201-218.

Frosch, K. and Tivig, T. (2009). Age, human capital and the geography of innovation. In Kuhn, M. and Ochsen, C., editors, Labour Markets and Demographic Change, pages 137-146. VS Verlag fuer Sozialwissenschaften. 
Giese, E. (2002). The spatial pattern of invention activities in West Germany 1992-1994. In Technological change and regional development in Europe, pages 9-27. Physica Verlag, Heidelberg, New York.

Giese, E. and von Reinhard Stoutz (1998). Indikatorfunktion von Patentanmeldungen für regionalanalytische Zwecke in der Bundesrepublik Deutschland. Raumforschung und Raumordnung, $56(5-6): 414-420$.

Göbel, C. and Zwick, T. (2012). Age and productivity: Sector differences. De Economist, 160(1):35-57.

Gregory, T. and Patuelli, R. (2013). Regional age structure, human capital and innovation Is demographic ageing increasing regional disparities? ZEW Discussion Paper No. 13-057, Center for European Economic Research.

Griliches, Z. (1979). Issues in assessing the contribution of R\&D to productivity growth. Bell Journal of Economics, pages 92-116.

Griliches, Z. (1987). RESD, patents and productivity. University of Chicago Press.

Griliches, Z. (1998). Patent statistics as economic indicators: A survey. In RED and Productivity: The Econometric Evidence, pages 287-343. University of Chicago Press.

Haltiwanger, J. C., Lane, J. I., and Spletzer, J. R. (1999). Productivity differences across employers: The roles of employer size, age, and human capital. American Economic Review, $89(2): 94-98$.

Hellerstein, J. K., Neumark, D., and Troske, K. R. (1996). Wages, productivity, and worker characteristics: Evidence from plant-level production functions and wage equations. Technical report, National Bureau of Economic Research.

Horn, J. L. and Cattell, R. B. (1967). Age differences in fluid and crystallized intelligence. Acta Psychologica, 26:107-129.

Hunt, J. (2004). Are migrants more skilled than non-migrants? Repeat, return, and sameemployer migrants. Canadian Journal of Economics, 37(4):830-849.

Jaffe, A. B. (1989). Real effects of academic research. American Economic Review, 79(5):957-70. 
Jones, B. F. (2010). Age and great invention. The Review of Economics and Statistics, 92(1):114.

Kosfeld, R. and Werner, A. (2012). Deutsche Arbeitsmarktregionen - Neuabgrenzung nach den Kreisgebietsreformen 2007-2011. Raumforschung und Raumordnung, 70(1):49-64.

Kulu, H. (2008). Fertility and spatial mobility in the life course: Evidence from Austria. Environment and planning. A, 40(3):632.

Lallemand, T. and Rycx, F. (2009). Are older workers harmful for firm productivity? De Economist, 157(3):273-292.

Lehman, H. C. (1953). Age and achievement. Princeton University Press.

Lindh, T. and Malmberg, B. (1999). Age structure effects and growth in the OECD, 1950-1990. Journal of Population Economics, 12(3):431-449.

Malecki, E. (1997). Technology and economic development: The dynamics of local, regional and national competitiveness. Addison Wesley Longman.

Manski, C. (2000). Economic analysis of social interations. Journal of Economic Perspectives, 14(3):115-136.

Möller, J. and Tubadji, A. (2009). The creative class, bohemians and local labor market performance. Journal of Economics and Statistics, 229.

Moretti, E. (2012). The new geography of jobs. Houghton Mifflin Harcourt.

Oster, S. M. and Hamermesh, D. S. (1998). Aging and productivity among economists. Review of Economics and Statistics, 80(1):154-156.

Peri, G. (2005). Determinants of knowledge flows and their effect on innovation. Review of Economics and Statistics, 87(2):308-322.

Prskawetz, A., Mahlberg, B., and Skirbekk, V. (2007). Firm productivity, workforce age and educational structure in austrian industries in 2001. In Clark, R., Hiro, O., and Mason, A., editors, Population Aging, Intergenerational Transfers and the Macroeconomy. Edward Elgar Publishing. 
Sato, R. and Koizumi, T. (1973). On the elasticities of substitution and complementarity. Oxford Economic Papers, pages 44-56.

Scherer, F. (1983). The propensity to patent. International Journal of Industrial Organization, 1(1):107-128.

Schneider, L. (2008). Aging and technological innovativeness - A linked employer-employee analysis. Comparative Population Studies, 33(1):37-54.

Simonton, D. K. (1988). Age and outstanding achievement: What do we know after a century of research? Psychological Bulletin, 104(2):251.

Skirbekk, V. (2004). Age and individual productivity: A literature survey. Vienna Yearbook of Population Research, 1(1):133-153.

Van Ours, J. C. and Stoeldraijer, L. (2011). Age, wage and productivity in dutch manufacturing. De Economist, 159(2):113-137.

Von Hippel, E. (1994). 'Sticky information' and the locus of problem solving: Implications for innovation. Management Science, 40(4):429-439. 


\section{A Appendix}

\section{A.1 Definition of the creative class}

\begin{tabular}{lcl}
\hline SIAB 7508 & SIAB-R 7508 (SUF) & Occupational title (German) \\
\hline Creative Professionals & & \\
621 & 64 & Maschinenbautechniker \\
622,623 & 65 & Techniker des Elektrofaches bis Bautechniker \\
$624,625,626,627$ & 66 & Vermessungstechniker bis übrige Fertigungstechniker \\
628 & 67 & Sonstige Techniker \\
629 & 68 & Industriemeister, Werkmeister \\
631,632 & 69 & Biologischtechnische Sonderfachkräfte bis physi- \\
& & kalisch-, mathematisch-technische Sonderfachkräfte \\
633,634 & 70 & Chemielaboraten bis Photolaboranten \\
635 & 71 & Technische Zeichner \\
691,692 & 76 & Bankfachleute bis Bausparkassenfachleute \\
751 & 87 & Unternehmer, Geschäftsführer, Geschäftsbe-reichsleiter \\
752,753 & 88 & Unternehmensberater, Organisatoren bis Wirt- \\
774 & 92 & schaftsprüfer, Steuerberater \\
\hline Bohemians & & Datenverarbeitungsfachleute \\
$821,822,823$ & 99 & Publizisten bis Bibliothekare, Archivare, Museumsfachleute \\
$831,832,833,834$ & 100 & Musiker bis Dekorationen-, Schildermaler \\
$835,836,837,838$ & 101 & Künstlerische und zugeordnete Berufe der Büh- \\
& & nen-, Bild-, Tontechnik bis Artisten, Berufssport- \\
& & ler, künstlerische Hilfsberufe \\
\hline Notes: classification according to &
\end{tabular}

Notes: classification according to (Möller and Tubadji, 2009]. 


\section{A.2 First stage estimates for IV regressions in Table 2}

\begin{tabular}{|c|c|c|}
\hline Dependent variable: & $\begin{array}{c}\text { average } \\
\text { workforce age } \\
\text { (1) }\end{array}$ & $\begin{array}{c}\text { average } \\
\text { workforce age } \\
\text { squared } \\
(2)\end{array}$ \\
\hline \multicolumn{3}{|l|}{ R\&D INPUTS } \\
\hline private RaD exp. (log, in 100 tsd Euro) & $\begin{array}{c}-0.01 \\
(-0.18)\end{array}$ & $\begin{array}{l}-1.01 \\
(-0.19)\end{array}$ \\
\hline public RaD exp. (log, in 100 tsd Euro) & $\begin{array}{l}-0.05 \\
(-1.43)\end{array}$ & $\begin{array}{l}-3.54 \\
(-1.41)\end{array}$ \\
\hline \multicolumn{3}{|l|}{ HUMAN CAPITAL INPUTS } \\
\hline num. of creative professionals (in log) & $\begin{array}{l}-0.10 \\
(-0.23)\end{array}$ & $\begin{array}{l}-8.52 \\
(-0.24)\end{array}$ \\
\hline population density (log) & $\begin{array}{c}0.24^{* *} \\
(2.19)\end{array}$ & $\begin{array}{c}19.69^{* *} \\
(2.23)\end{array}$ \\
\hline workforce size (log, in tsd) & $\begin{array}{c}0.32 \\
(0.77)\end{array}$ & $\begin{array}{l}25.77 \\
(0.78)\end{array}$ \\
\hline \multicolumn{3}{|l|}{ INSTRUMENTS $($ YEAR=1985) } \\
\hline lagged number of bohemians & $\begin{array}{c}-0.23^{* *} \\
(-2.09)\end{array}$ & $\begin{array}{c}-18.21^{* *} \\
(-2.08)\end{array}$ \\
\hline lagged population ratio & $\begin{array}{l}-0.10^{*} \\
(-1.85)\end{array}$ & $\begin{array}{l}-7.62^{*} \\
(-1.84)\end{array}$ \\
\hline lagged share of workers in public sector & $\begin{array}{l}-0.07^{*} \\
(-1.95)\end{array}$ & $\begin{array}{l}-5.73^{*} \\
(-1.97)\end{array}$ \\
\hline constant & $\begin{array}{c}48.90^{* * *} \\
(7.88)\end{array}$ & $\begin{array}{c}2302.77^{* * *} \\
(4.67)\end{array}$ \\
\hline $\mathrm{N}$ & 108 & 108 \\
\hline R-squared & 0.646 & 0.646 \\
\hline $\mathrm{F}$ & 6.7 & 6.9 \\
\hline F-Test of excluded instruments & 4.2 & 4.2 \\
\hline
\end{tabular}

Notes: t-statistics in parentheses ${ }^{*} \mathrm{p}<0.10,{ }^{* *} \mathrm{p}<0.05,{ }^{* * *} \mathrm{p}<0.01$. Standard errors are clustered by region. All models include regional industry shares. 


\section{A.3 Robustness checks for estimations in Table 2 (West Germany)}

\begin{tabular}{|c|c|c|c|c|c|c|}
\hline \multirow{3}{*}{ Dependent variable: } & \multicolumn{2}{|c|}{ Cross-Section } & \multicolumn{4}{|c|}{ PANel } \\
\hline & \multicolumn{2}{|c|}{ Number of citations $(\log )$} & \multicolumn{4}{|c|}{ Number of patents $(\log )$} \\
\hline & $\begin{array}{c}\text { OLS } \\
(1)\end{array}$ & $\begin{array}{l}\text { IV } \\
(2)\end{array}$ & $\begin{array}{c}\text { POLS } \\
(3)\end{array}$ & $\begin{array}{c}\text { POLS-IV } \\
\quad(4)\end{array}$ & $\begin{array}{l}\mathrm{FE} \\
(5)\end{array}$ & $\begin{array}{c}\text { FE-IV } \\
(6)\end{array}$ \\
\hline \multicolumn{7}{|l|}{ R\&D INPUTS } \\
\hline private RaD exp. (log, in 100 tsd Euro) & $\begin{array}{c}0.32^{* * *} \\
(5.35)\end{array}$ & $\begin{array}{c}0.30 * * * \\
(4.32)\end{array}$ & $\begin{array}{c}0.21^{* * * *} \\
(5.74)\end{array}$ & $\begin{array}{c}0.19^{* *} \\
(2.54)\end{array}$ & $\begin{array}{c}-0.01 \\
(-0.48)\end{array}$ & $\begin{array}{c}-0.02 \\
(-0.82)\end{array}$ \\
\hline public RaD exp. (log, in 100 tsd Euro) & $\begin{array}{c}0.01 \\
(0.41)\end{array}$ & $\begin{array}{c}0.03 \\
(0.80)\end{array}$ & $\begin{array}{l}-0.00 \\
(-0.01)\end{array}$ & $\begin{array}{c}0.02 \\
(0.39)\end{array}$ & $\begin{array}{c}-0.02 \\
(-0.62)\end{array}$ & $\begin{array}{l}-0.00 \\
(-0.01)\end{array}$ \\
\hline \multicolumn{7}{|l|}{ HUMAN CAPITAL INPUTS } \\
\hline average workforce age & $\begin{array}{c}15.55^{* * * *} \\
(2.92)\end{array}$ & $\begin{array}{c}59.98 \\
(1.38)\end{array}$ & $\begin{array}{c}4.61^{* * *} \\
(3.37)\end{array}$ & $\begin{array}{l}-9.42 \\
(-0.58)\end{array}$ & $\begin{array}{c}0.08 \\
(0.07)\end{array}$ & $\begin{array}{l}-2.74 \\
(-1.15)\end{array}$ \\
\hline average workforce age (squared) & $\begin{array}{c}-0.20^{* * *} \\
(-2.92)\end{array}$ & $\begin{array}{l}-0.75 \\
(-1.38)\end{array}$ & $\begin{array}{c}-0.06^{* * *} \\
(-3.44)\end{array}$ & $\begin{array}{c}0.13 \\
(0.59)\end{array}$ & $\begin{array}{c}-0.00 \\
(-0.10)\end{array}$ & $\begin{array}{c}0.04 \\
(1.25)\end{array}$ \\
\hline num. of creative professionals (in log) & $\begin{array}{l}-0.15 \\
(-0.44)\end{array}$ & $\begin{array}{l}-0.52 \\
(-1.09)\end{array}$ & $\begin{array}{c}0.33 \\
(1.19)\end{array}$ & $\begin{array}{c}0.58 \\
(1.27)\end{array}$ & $\begin{array}{c}-0.23 \\
(-0.86)\end{array}$ & $\begin{array}{c}-0.35 \\
(-1.03)\end{array}$ \\
\hline \multicolumn{7}{|l|}{ REGIONAL INDICATORS } \\
\hline population density (log) & $\begin{array}{l}0.16^{*} \\
(1.70)\end{array}$ & $\begin{array}{c}0.37 \\
(1.54)\end{array}$ & $\begin{array}{c}0.11 \\
(1.23)\end{array}$ & $\begin{array}{l}-0.16 \\
(-0.39)\end{array}$ & $\begin{array}{c}-0.61 \\
(-0.40)\end{array}$ & $\begin{array}{c}1.52 \\
(0.75)\end{array}$ \\
\hline workforce size (log, in tsd) & $\begin{array}{c}0.72^{* *} \\
(2.14)\end{array}$ & $\begin{array}{l}1.04^{* *} \\
(2.28)\end{array}$ & $\begin{array}{c}0.40 \\
(1.50)\end{array}$ & $\begin{array}{c}0.22 \\
(0.51)\end{array}$ & $\begin{array}{c}0.93 \\
(1.32)\end{array}$ & $\begin{array}{c}1.19 \\
(1.34)\end{array}$ \\
\hline constant & $\begin{array}{c}-314.05^{* * *} \\
(-2.96)\end{array}$ & $\begin{array}{c}-1193.69 \\
(-1.39)\end{array}$ & $\begin{array}{c}-96.73^{* * *} \\
(-3.54)\end{array}$ & $\begin{array}{l}165.06 \\
(0.54)\end{array}$ & $\begin{array}{c}2.87 \\
(0.13) \\
\end{array}$ & \\
\hline $\mathrm{N}$ & 108 & 108 & 432 & 432 & 432 & 432 \\
\hline R-squared & 0.952 & 0.912 & 0.920 & 0.839 & 0.407 & 0.212 \\
\hline $\mathrm{F}$ & 118.7 & 57.9 & 126.9 & 76.9 & 12.1 & 7.2 \\
\hline Hansen (j-statistic) & & 0.288 & & 0.253 & & 0.009 \\
\hline Hansen (p-value) & & 0.591 & & 0.615 & & 0.923 \\
\hline
\end{tabular}

Notes: $\mathrm{t}$ statistics in parentheses ${ }^{*} \mathrm{p}<0.10,{ }^{* *} \mathrm{p}<0.05,{ }^{* * *} \mathrm{p}<0.01$. Standard errors are clustered by region. All IV-models in this table are estimated with 2SLS. All models include regional industry shares. 


\section{A.4 Cross-sectional estimates for a sample with East and West Germany}

\begin{tabular}{|c|c|c|c|c|}
\hline \multirow[t]{2}{*}{ Dependent variable: number of patents $(\log )$} & \multicolumn{2}{|c|}{ OLS } & \multicolumn{2}{|c|}{ IV } \\
\hline & (1) & $(2)$ & $\begin{array}{c}\text { 2SLS } \\
(3)\end{array}$ & $\begin{array}{l}\text { LIML } \\
(4)\end{array}$ \\
\hline \multicolumn{5}{|l|}{ R\&D INPUTS } \\
\hline private $\mathrm{RaD}$ exp. (log, in 100 tsd Euro) & $\begin{array}{c}0.44^{* * *} \\
(7.41)\end{array}$ & $\begin{array}{c}0.34^{* * *} \\
(6.53)\end{array}$ & $\begin{array}{c}0.35^{* * *} \\
(6.35)\end{array}$ & $\begin{array}{c}0.36^{* * * *} \\
(5.16)\end{array}$ \\
\hline public RaD exp. (log, in 100 tsd Euro) & $\begin{array}{c}0.02 \\
(0.97)\end{array}$ & $\begin{array}{c}0.03 \\
(1.36)\end{array}$ & $\begin{array}{c}0.03 \\
(1.19)\end{array}$ & $\begin{array}{c}0.02 \\
(0.95)\end{array}$ \\
\hline \multicolumn{5}{|l|}{ HUMAN CAPITAL INPUTS } \\
\hline average workforce age & $\begin{array}{c}19.90^{* * *} \\
(3.86)\end{array}$ & $\begin{array}{c}21.01^{* * *} \\
(4.87)\end{array}$ & $\begin{array}{l}14.55 \\
(0.60)\end{array}$ & $\begin{array}{l}10.29 \\
(0.27)\end{array}$ \\
\hline average workforce age (squared) & $\begin{array}{c}-0.25^{* * *} \\
(-3.88)\end{array}$ & $\begin{array}{c}-0.27^{* * *} \\
(-4.90)\end{array}$ & $\begin{array}{c}-0.18 \\
(-0.61)\end{array}$ & $\begin{array}{c}-0.13 \\
(-0.28)\end{array}$ \\
\hline num. of creative professionals (in log) & $\begin{array}{c}0.44^{* * *} \\
(4.38)\end{array}$ & $\begin{array}{c}0.28 \\
(0.95)\end{array}$ & $\begin{array}{c}0.31 \\
(1.06)\end{array}$ & $\begin{array}{c}0.33 \\
(1.02)\end{array}$ \\
\hline \multicolumn{5}{|l|}{ REGIONAL INDICATORS } \\
\hline dummy for East Germany & $\begin{array}{c}-0.45^{* * *} \\
(-3.08)\end{array}$ & $\begin{array}{l}-0.11 \\
(-0.57)\end{array}$ & $\begin{array}{l}-0.16 \\
(-0.65)\end{array}$ & $\begin{array}{c}-0.19 \\
(-0.65)\end{array}$ \\
\hline population density (log) & & $\begin{array}{c}0.24^{* * *} \\
(2.92)\end{array}$ & $\begin{array}{c}0.22^{* *} \\
(2.57)\end{array}$ & $\begin{array}{l}0.21^{* *} \\
(2.03)\end{array}$ \\
\hline workforce size (log, in tsd) & & $\begin{array}{c}0.16 \\
(0.57)\end{array}$ & $\begin{array}{c}0.13 \\
(0.45)\end{array}$ & $\begin{array}{c}0.11 \\
(0.35)\end{array}$ \\
\hline constant & $\begin{array}{c}-394.11^{* * *} \\
(-3.83)\end{array}$ & $\begin{array}{c}-424.25^{* * *} \\
(-4.98)\end{array}$ & $\begin{array}{c}-296.75 \\
(-0.62)\end{array}$ & $\begin{array}{r}-212.20 \\
(-0.28) \\
\end{array}$ \\
\hline With industry shares? & no & yes & yes & yes \\
\hline $\mathrm{N}$ & 141 & 141 & 141 & 141 \\
\hline R-squared & 0.923 & 0.952 & 0.951 & 0.950 \\
\hline $\mathrm{F}$ & 260.0 & 164.3 & 161.9 & 156.2 \\
\hline Hansen (j-statistic) & & & 1.386 & 1.288 \\
\hline Hansen (p-value) & & & 0.239 & 0.256 \\
\hline
\end{tabular}

Notes: t-statistics in parentheses ${ }^{*} \mathrm{p}<0.10,{ }^{* *} \mathrm{p}<0.05,{ }^{* * *} \mathrm{p}<0.01$. Standard errors are clustered by region.

\section{A.5 Testing different functional forms}

\begin{tabular}{lcc}
\hline & LR $\chi^{2}$ & Prob $>\chi^{2}$ \\
\hline CES & 274.35 & 0.0000 \\
Cobb-Douglas & 15.03 & 0.0018 \\
Translog & 2.81 & 0.4225 \\
\hline Observations & 108 & 108 \\
\hline
\end{tabular}




\section{A.6 Estimates from Translog production functions for Table 3}

\begin{tabular}{|c|c|c|c|c|}
\hline \multirow[t]{2}{*}{ Dependent variable: $\log$ number of patents } & \multicolumn{2}{|c|}{ West Germany } & \multicolumn{2}{|c|}{ Germany } \\
\hline & $\begin{array}{c}\text { OLS } \\
(1)\end{array}$ & $\begin{array}{c}\text { IV } 2 \text { SLS } \\
(2)\end{array}$ & $\begin{array}{c}\text { OLS } \\
(3)\end{array}$ & $\begin{array}{c}\text { IV } 2 \text { SLS } \\
(4)\end{array}$ \\
\hline \multicolumn{5}{|l|}{ R\&D INVESTMENTS } \\
\hline private $\mathrm{RaD}$ exp. (log, in 100 tsd Euro) & $\begin{array}{c}0.28^{* * *} \\
(4.91)\end{array}$ & $\begin{array}{c}0.31^{* * * *} \\
(4.67)\end{array}$ & $\begin{array}{c}0.33^{* * *} \\
(6.27)\end{array}$ & $\begin{array}{c}0.52^{* *} \\
(2.17)\end{array}$ \\
\hline public RaD exp. (log, in 100 tsd Euro) & $\begin{array}{c}0.01 \\
(0.53)\end{array}$ & $\begin{array}{c}0.02 \\
(0.71)\end{array}$ & $\begin{array}{c}0.03 \\
(1.25)\end{array}$ & $\begin{array}{c}0.06 \\
(0.51)\end{array}$ \\
\hline \multicolumn{5}{|l|}{ HUMAN CAPITAL INPUTS } \\
\hline number of young workers (log) & $\begin{array}{c}2.21 \\
(0.39)\end{array}$ & 39.06 & $\begin{array}{c}8.04 \\
(1.23)\end{array}$ & $\begin{array}{l}28.40 \\
(0.24)\end{array}$ \\
\hline number of middle-aged workers (log) & $\begin{array}{l}-5.53 \\
(-0.36)\end{array}$ & $\begin{array}{l}-33.38 \\
(-1.17)\end{array}$ & $\begin{array}{l}-11.57 \\
(-0.70)\end{array}$ & $\begin{array}{l}28.35 \\
(0.08)\end{array}$ \\
\hline number of older workers (log) & $\begin{array}{c}4.86 \\
(0.46)\end{array}$ & $\begin{array}{l}-3.27 \\
(-0.12)\end{array}$ & $\begin{array}{c}4.29 \\
(0.41)\end{array}$ & $\begin{array}{l}-74.16 \\
(-0.34)\end{array}$ \\
\hline number of young workers (log) squared & $\begin{array}{c}-1.35 \\
(-0.86)\end{array}$ & $\begin{array}{c}5.51 \\
(1.44)\end{array}$ & $\begin{array}{c}0.11 \\
(0.08)\end{array}$ & $\begin{array}{l}1.27 \\
(0.10)\end{array}$ \\
\hline number of middle-aged workers (log) squared & $\begin{array}{c}3.82 \\
(0.62)\end{array}$ & $\begin{array}{l}14.38 \\
(0.99)\end{array}$ & $\begin{array}{c}6.41 \\
(0.90)\end{array}$ & $\begin{array}{l}-41.81 \\
(-0.33)\end{array}$ \\
\hline number of older workers $(\log )$ squared & $\begin{array}{c}-2.84 \\
(-0.88)\end{array}$ & $\begin{array}{l}-15.32 \\
(-1.48)\end{array}$ & $\begin{array}{l}-3.98 \\
(-1.24)\end{array}$ & $\begin{array}{l}-55.62 \\
(-1.02)\end{array}$ \\
\hline young workers $\times$ middle-aged workers & $\begin{array}{c}-5.19 \\
(-1.03)\end{array}$ & $\begin{array}{c}-35.21^{* * *} \\
(-4.18)\end{array}$ & $\begin{array}{c}-10.34^{*} \\
(-1.84)\end{array}$ & $\begin{array}{l}-8.65 \\
(-0.10)\end{array}$ \\
\hline middle-aged workers $\times$ older workers & $\begin{array}{c}-3.13 \\
(-0.37)\end{array}$ & $\begin{array}{c}6.19 \\
(0.25)\end{array}$ & $\begin{array}{c}-2.98 \\
(-0.33)\end{array}$ & $\begin{array}{l}102.79 \\
(0.62)\end{array}$ \\
\hline young workers $\times$ middle-aged workers & $\begin{array}{c}8.67^{* *} \\
(2.39)\end{array}$ & $\begin{array}{c}24.38^{* * *} \\
(2.83)\end{array}$ & $\begin{array}{c}10.78^{* * * *} \\
(3.01)\end{array}$ & $\begin{array}{c}2.36 \\
(0.03)\end{array}$ \\
\hline num. of creative professionals (in log) & $\begin{array}{c}0.00 \\
(0.01)\end{array}$ & $\begin{array}{c}-0.68 \\
(-1.31)\end{array}$ & $\begin{array}{c}0.30 \\
(1.00)\end{array}$ & $\begin{array}{c}2.55 \\
(0.85)\end{array}$ \\
\hline \multicolumn{5}{|l|}{ REGIONAL INDICATORS } \\
\hline $\begin{array}{l}\text { population density (log) } \\
\text { dummy for East Germany }\end{array}$ & $\begin{array}{c}0.28^{* *} \\
(2.52)\end{array}$ & $\begin{array}{l}0.32^{*} \\
(1.82)\end{array}$ & $\begin{array}{c}0.37 * * * \\
(3.50) \\
-0.14 \\
(-0.67)\end{array}$ & $\begin{array}{c}0.52 \\
(1.04) \\
-0.10 \\
(-0.24)\end{array}$ \\
\hline constant & $\begin{array}{c}-7.59 \\
(-0.76) \\
\end{array}$ & $\begin{array}{c}9.97 \\
(0.47) \\
\end{array}$ & $\begin{array}{c}-7.63 \\
(-0.75) \\
\end{array}$ & $\begin{array}{l}25.79 \\
(0.10) \\
\end{array}$ \\
\hline $\mathrm{N}$ & 108 & 108 & 141 & 141 \\
\hline R-squared & 0.958 & 0.920 & 0.955 & 0.708 \\
\hline $\mathrm{F}$ & & 38761.5 & & 48.1 \\
\hline Hansen (j-statistic) & & 8.620 & & 0.143 \\
\hline Hansen (p-value) & & 0.196 & & 0.705 \\
\hline
\end{tabular}

Notes: t-statistics in parentheses $* \mathrm{p}<0.10,{ }^{* *} \mathrm{p}<0.05,{ }^{* * *} \mathrm{p}<0.01$. Standard errors are clustered by region. All models include regional industry shares. 


\section{A.7 Robustness of structural estimates in Table 3}

\begin{tabular}{|c|c|c|c|c|c|c|}
\hline & \multirow{2}{*}{\multicolumn{2}{|c|}{$\begin{array}{c}\text { WeSt-GERMANY } \\
(\mathrm{N}=108) \\
\text { Citations }\end{array}$}} & \multicolumn{4}{|c|}{$\begin{array}{c}\text { GERMANY } \\
(\mathrm{N}=141)\end{array}$} \\
\hline & & & \multicolumn{2}{|c|}{ Citations } & \multicolumn{2}{|c|}{ Patent counts } \\
\hline & OLS & IV & OLS & IV & OLS & IV \\
\hline & $(1)$ & $(2)$ & $(3)$ & $(4)$ & $(5)$ & $(6)$ \\
\hline predicted patents & $\begin{array}{c}361.65^{* * *} \\
(7.08)\end{array}$ & $\begin{array}{c}340.66 \\
(0.00)\end{array}$ & $\begin{array}{c}278.30^{* * *} \\
(16.89)\end{array}$ & $\begin{array}{c}263.42^{* * *} \\
(7.58)\end{array}$ & $\begin{array}{c}155.21^{* * *} \\
(11.17)\end{array}$ & $\begin{array}{c}154.59^{* * *} \\
(6.58)\end{array}$ \\
\hline \multicolumn{7}{|l|}{ MARGINAL PRODUCTS } \\
\hline young workers $\left(\mu_{1}\right)$ & $\begin{array}{c}1.72^{* * *} \\
(2.65)\end{array}$ & $\begin{array}{c}1.76 \\
(0.00)\end{array}$ & $\begin{array}{c}0.98^{* *} \\
(2.05)\end{array}$ & $\begin{array}{c}1.66 \\
(0.70)\end{array}$ & $\begin{array}{c}0.83^{* * *} \\
(3.07)\end{array}$ & $\begin{array}{c}1.98 \\
(1.30)\end{array}$ \\
\hline middle-aged workers $\left(\mu_{2}\right)$ & $\begin{array}{c}-0.13 \\
(-0.49)\end{array}$ & $\begin{array}{c}0.16 \\
(0.00)\end{array}$ & $\begin{array}{c}0.22 \\
(1.17)\end{array}$ & $\begin{array}{c}0.31 \\
(0.45)\end{array}$ & $\begin{array}{c}0.08 \\
(0.84)\end{array}$ & $\begin{array}{c}0.22 \\
(0.39)\end{array}$ \\
\hline older workers $\left(\mu_{3}\right)$ & $\begin{array}{c}-0.52 \\
(-0.98)\end{array}$ & $\begin{array}{c}-0.87 \\
(-0.64)\end{array}$ & $\begin{array}{c}-1.17^{* * *} \\
(-2.91)\end{array}$ & $\begin{array}{c}-1.66 \\
(-1.14)\end{array}$ & $\begin{array}{c}-0.84^{* * *} \\
(-3.57)\end{array}$ & $\begin{array}{l}-1.93^{*} \\
(-1.93)\end{array}$ \\
\hline \multicolumn{7}{|l|}{ SECOND ORDER DERIVATIVES } \\
\hline young and middle-aged workers $\left(\sigma_{12}\right)$ & $\begin{array}{c}0.02 \\
(1.61)\end{array}$ & $\begin{array}{c}0.08 \\
(1.34)\end{array}$ & $\begin{array}{c}0.01 \\
(0.48)\end{array}$ & $\begin{array}{c}0.05^{* *} \\
(2.14)\end{array}$ & $\begin{array}{c}0.00 \\
(0.42)\end{array}$ & $\begin{array}{c}0.02 \\
(1.17)\end{array}$ \\
\hline young and older workers $\left(\sigma_{13}\right)$ & $\begin{array}{c}0.01^{* *} \\
(2.13)\end{array}$ & $\begin{array}{c}0.02 \\
(0.75)\end{array}$ & $\begin{array}{c}0.00 \\
(1.01)\end{array}$ & $\begin{array}{c}0.02^{* * *} \\
(3.16)\end{array}$ & $\begin{array}{c}0.00 \\
(0.90)\end{array}$ & $\begin{array}{c}0.01 \\
(1.03)\end{array}$ \\
\hline middle-aged and older workers $\left(\sigma_{23}\right)$ & $\begin{array}{c}0.00 \\
(0.12) \\
\end{array}$ & $\begin{array}{c}-0.03 \\
(-0.60) \\
\end{array}$ & $\begin{array}{c}-0.00 \\
(-0.24)\end{array}$ & $\begin{array}{c}0.00 \\
(0.14)\end{array}$ & $\begin{array}{c}-0.00 \\
(-0.28)\end{array}$ & $\begin{array}{c}0.02 \\
(0.66)\end{array}$ \\
\hline \multicolumn{7}{|l|}{ CROSS-PARTIAL DERIVATIVES } \\
\hline young and middle-aged workers $\left(\sigma_{12}\right)$ & $\begin{array}{c}-0.02^{* * *} \\
(-2.78)\end{array}$ & $\begin{array}{l}-0.05 \\
(-1.14)\end{array}$ & $\begin{array}{l}-0.01^{*} \\
(-1.74)\end{array}$ & $\begin{array}{c}-0.03^{* *} \\
(-2.43)\end{array}$ & $\begin{array}{l}-0.00^{*} \\
(-1.72)\end{array}$ & $\begin{array}{c}-0.01 \\
(-1.25)\end{array}$ \\
\hline young and older workers $\left(\sigma_{13}\right)$ & $\begin{array}{c}0.03^{* * *} \\
(2.68)\end{array}$ & $\begin{array}{c}0.07 \\
(0.97)\end{array}$ & $\begin{array}{c}0.02^{* *} \\
(2.54)\end{array}$ & $\begin{array}{c}0.05^{* *} \\
(2.30)\end{array}$ & $\begin{array}{c}0.01^{* *} \\
(2.12)\end{array}$ & $\begin{array}{c}0.02 \\
(0.58)\end{array}$ \\
\hline middle-aged and older workers $\left(\sigma_{23}\right)$ & $\begin{array}{c}-0.01 \\
(-1.43)\end{array}$ & $\begin{array}{l}-0.01 \\
(-0.28)\end{array}$ & $\begin{array}{l}-0.00 \\
(-0.65)\end{array}$ & $\begin{array}{c}-0.02^{* * *} \\
(-3.00)\end{array}$ & $\begin{array}{l}-0.00 \\
(-0.46)\end{array}$ & $\begin{array}{l}-0.01 \\
(-0.78)\end{array}$ \\
\hline
\end{tabular}

Notes: The table presents estimates at the mean of the sample. t-statistics in parenthesis; calculated based on Deltamethod. Significance levels: ${ }^{*} \mathrm{p}<0.10,{ }^{* *} \mathrm{p}<0.05,{ }^{* * *} \mathrm{p}<0.01$. IV-models are estimated with 2SLS. Coefficients reflect absolute increases per 100 additional workers. 